\title{
The Natural Resource Curse, Fiscal Decentralization, and Agglomeration Economies*
}

\author{
Fidel Perez-Sebastian \\ University of Alicante \\ fidel.perez.sebastian@gmail.com
}

\author{
Ohad Raveh ${ }^{\dagger}$ \\ Hebrew University of Jerusalem \\ ohad.raveh@mail.huji.ac.il
}

May 2012

\begin{abstract}
Natural resource abundance is a blessing for some countries, but a curse for others. We show that differences across countries in the degree of fiscal decentralization can contribute to this divergent outcome. The paper first employs Sachs and Warner's cross-sectional data and finds support for the novel hypothesis. Then, it constructs a new panel-data sample that confirms the results. We also offer a theory of inter-regional tax competition that rationalizes the findings. The theory emphasizes misallocations caused by the lack of co-movement of labor and capital towards less agglomerated and more isolated areas where natural riches are located.
\end{abstract}

Keywords: Natural resources, economic growth, fiscal decentralization, agglomeration, input misallocation, tax competition

JEL classification: O13, O18, O40, Q32

*Fidel Perez-Sebastian thanks the Spanish Ministry of Science and Technology (SEJ 2007-62656 and FEDER funds), and the Instituto Valenciano de Investigaciones Económicas for financial support. Ohad Raveh is grateful to Omer Moav and Nathan Sussman for their guidance and support, and to the Social Sciences and Humanities Research Council of Canada for financial support. We are also thankful to seminar participants at Bar-Ilan University and Hebrew University of Jerusalem, as well as to Elissaios Papyrakis for helpful comments and suggestions.

${ }^{\dagger}$ Correspondance to: Ohad Raveh, Economics Department, Hebrew University of Jerusalem, Mt. Scopus, Jerusalem, 91905, Israel. 


\section{Introduction}

Since the influential works of Sachs and Warner $(1997,1999,2001)$ the so-called resource curse puzzle, describing an inverse relationship between resource abundance and economic growth, has attracted considerable attention. Further studies have provided additional empirical evidence of this phenomenon as well as various potential explanations for its occurrence. Among these explanations, the literature has emphasized political factors, corruption, underdeveloped legal and financial systems, Dutch Disease mechanisms, or human-capital inhibiting institutions. ${ }^{1}$

This paper contributes to this strand of the literature, presenting a novel explanation: the level of fiscal decentralization. Fiscal decentralization comprises the financial aspects of devolution to regional and local governments, and it covers two main interrelated issues. The first is the division of spending responsibilities and revenue sources between levels of government. The second is the amount of discretion given to regional and local governments to determine their expenditure and revenues. The definition that we adopt concerns both issues, yet emphasizes the latter. Our main hypothesis is that fiscally decentralized economies are more vulnerable to the growth curse of natural resources than fiscally centralized ones.

Figure 1 illustrates the potential of this variable to explain the curse. The figure plots the average annual real per capita GDP growth from 1970 to 1990 versus the share of mineral output in total GDP in $1970 .^{2}$ Panel A is based on a sample of 52 countries, and provides a strong indication for an occurrence of a resource curse. In panels B and $\mathrm{C}$, the sample is split into two equal sub-samples according to the degree of fiscal decentralization in 1972. Results indicate that a resource curse appears in countries with a relatively higher degree of fiscal decentralization (panel B), yet it completely disappears in countries with a relatively lower degree of fiscal decentralization (panel C). ${ }^{3}$

\footnotetext{
${ }^{1}$ See, for example, recent surveys by Frankel (2010) and van der Ploeg (2011).

${ }^{2}$ An elaborated discussion over all variables employed in the paper and the samples appears in sub-section 3.1 of the empirical part as well as in appendix 2 .

${ }^{3}$ The fiscal decentralization proxy is Vertical Imbalance - the degree to which sub-national governments fund their expenditures through their own revenue sources. This index is taken from the World Bank's Fiscal Decentralization Indicators. The year 1972 is the earliest for which data is available. The countries in panel B are: Australia, Austria, Bolivia, Brazil, Canada, Costa Rica, Ecuador, Finland, West Germany, Greece, Guatemala, Honduras, Iran, Kenya, Mexico, New Zealand, Nicaragua, Pakistan, Paraguay, Senegal, Sri Lanka, Sweden, Switzerland, Uruguay, Venezuela, and Zambia. The countries in panel C are: Belgium, Chile, Colombia, Denmark, Dominican Republic, France, In-
} 
Figure 1: Average Annual Growth in Real GDP per Capita (1970-1990) and Resource Abundance
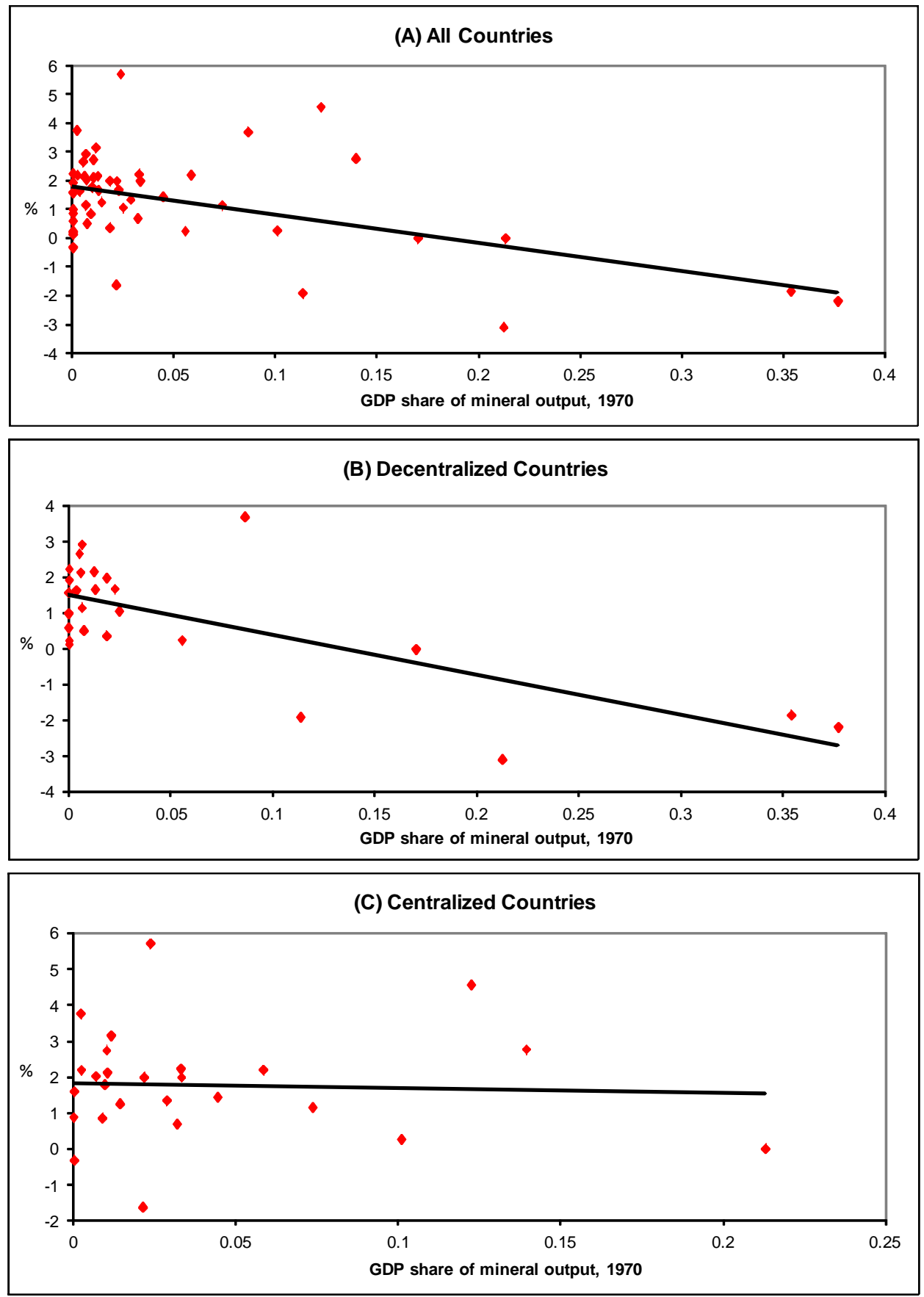
A more specific example is Venezuela versus Botswana. Both are heavily endowed with natural resources, yet the former experienced negative growth rates in the period of 1970-1990, while the latter presented one of the highest positive growth rates during that time. According to the Fiscal Decentralization Indicators of the World Bank, the economy of Venezuela is highly fiscally decentralized whereas that of Botswana is the most centralized in the sample. Let us consider other resource abundant countries. ${ }^{4}$ Some of the most fiscally centralized include Azerbaijan, Chile, Indonesia, Malaysia and Norway; all of which performed (growth-wise) remarkably well in the periods investigated in our samples. Conversely, some of the most fiscally decentralized nations include Ecuador, Ethiopia, Iran, Mexico, and Zambia; all of which performed rather poorly during the same time frames.

We present a model that postulates that this effect can be a consequence of tax competition among regions, and labor market peculiarities. ${ }^{5}$ When labor does not follow the movement of capital, and inputs display diminishing marginal returns, capital reallocations can be welfare reducing. In particular, if a region that enjoys a resource windfall finds optimal to reduce taxes, it will attract capital from other parts of the country; however, this can lead to a net loss in GDP for the country as a whole if the capital-labor misallocation effect offsets the increase in natural output.

Cross-regional differences in agglomeration levels contribute to generate and amplify the negative effect. As figure 2 illustrates for the U.S. case, resource rich regions enjoy lower agglomeration levels. ${ }^{6}$ We argue that the misallocation effect is precisely a consequence of these lower agglomeration levels that characterize resource abundant regions: ceteris paribus, labor prefers moving to agglomerated areas, whereas capital

dia, Indonesia, Ireland, Israel, Italy, Korea Republic, Malawi, Malaysia, Netherlands, Norway, Peru, Philippines, Portugal, Spain, Sudan, Thailand, Trinidad and Tobago, Tunisia, United Kingdom, and United States.

${ }^{4}$ For the purposes of the following examples, we consider a country to be resource abundant if it consistently has a share of mineral output in total GDP greater than 10 percent.

${ }^{5}$ Raveh (2012) studies a similar mechanism termed the Alberta Effect. It does not, however, consider agglomeration economies.

${ }^{6}$ The agglomeration index comes from Ciccone and Hall (1996). It measures the intensity of labor, human, and physical capital relative to physical space. The index is expressed as a number between one and two and ranks U.S. states according to their agglomeration level in 1988. Appendix 1 presents similar state-level graphs using population density to capture agglomeration for Australia, Brazil, Germany, Canada, Malaysia, Russia, India, and United Arab Emirates; all of them show similar negative relationships, implying that at regional levels resources indeed locate in non-agglomerated areas. Population density is a narrower concept than agglomeration, although the two variables are highly positively correlated. 
Figure 2: GDP share of Primary Sector in 1988 Vs. Agglomeration in U.S. States

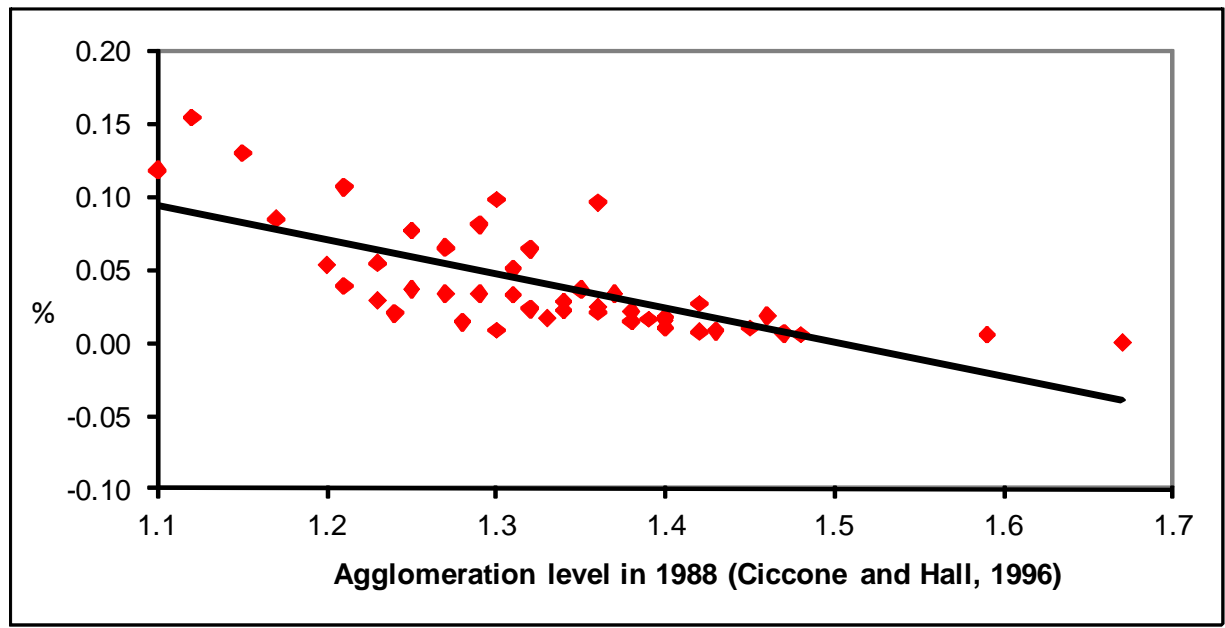

moves based on financial opportunities; we offer some evidence that supports this assertion. The model predicts that differences in agglomeration levels contribute as well to amplify the negative impact of a resource windfall on national income through the existence of agglomeration economies, because capital moves from areas in which it is relatively more productive to areas in which it is relatively less. ${ }^{7}$

The paper also presents empirical evidence for the main hypothesis, and key predictions of the model. We start by employing Sachs and Warner's (1997) data and methodology. We adopt the World Bank's Fiscal Decentralization Indicators to add a fiscal decentralization measure together with its interaction with the resource share proxy to the regressions; the time period is 1970-1990 over a sample of 52 countries. Results confirm the main hypothesis and show that the growth curse of natural resource amplifies in fiscally decentralized economies. These results hold when controlling for investment, openness, institutional quality, ethnicity, terms of trade, education, and interaction terms of ethnicity and institutional quality with the resource share proxy.

Departing from Sachs and Warner, we thereafter employ an extended sample of 74 countries over the period of 1972-2008 to test the same hypothesis through panel estimations, having largely the same controls as in the cross-sectional version, but in addition controlling for country and time fixed effects. The main result remains. By

\footnotetext{
${ }^{7}$ Introduced by Marshall (1920), the concept of agglomeration economies refers to the positive externalities of economic integration at the local level, especially with respect to increased labor market pooling, shared inputs, and knowledge spillovers.
} 
undertaking further checks, we conclude that the confirmation of our hypothesis is robust to using various fiscal decentralization and resource share measures, as well as to different estimation methods and time periods.

Other papers on the natural resource curse include the following. Lane and Tornell (1996) suggest that the existence of powerful groups in conjunction with weak institutions provide an explanation for the natural resource curse. Mehlum et al. (2006) argue that the quality of institutions is what matters. Hodler (2004) provides a similar argument for the level of fractionalization. Andersen and Aslaksen (2008) point at constitutional arrangements as a viable determinant. Gylfason et al. (1999), and Gylfason (2001) suggest that natural riches may develop a false sense of security and harm human capital accumulation. Rodriquez and Sachs (1999) and Guillo and PerezSebastian (2012) show that the negative effect can be an artifact of the dynamics induced by resource windfalls in the economy. In Caselli et al. (2011), geography is important, but these authors focus on the impact of natural resources on inter-state conflict.

The paper also contributes to the debate on the effect of fiscal decentralization and tax competition on economic growth. Since the seminal work of Tiebout (1956), a literature has emerged stressing the benefits of fiscal decentralization. For example, Oates (1972), Brennan and Buchanan (1980), and Qian and Roland (1998) argue that this can occur through a higher degree of discipline on local governments, better public services, and more efficient resource allocation, respectively. Other authors, however, argue that fiscal decentralization may introduce harming distortions that can prompt a race-to-the-bottom in local taxes and welfare provision - Zodrow and Mieszkowski (1986) - or produce overinvestment in infrastructure - Keen and Marchand (1997). As Martinez-Vazquez and McNab (2003) conclude in their survey of the literature, the effect still remains an open question. We contribute to this ongoing debate by emphasizing the potential adverse impact of fiscal decentralization transmitted through the resource abundance channel.

The paper is structured as follows. Section 2 presents the model, and performs a calibration exercise. Section 3 provides the empirical evidence. Section 4 concludes. 


\section{The Model}

In this section, we present a simple model that illustrates and evaluates mechanisms through which fiscal decentralization can interact with natural resources and affect income. These mechanisms are related to tax competition among regions. A detailed discussion of the main assumptions made in the model is presented at the end of the section.

\subsection{Regions}

Assume that there are $N$ small regions in a closed economy. ${ }^{8}$ Out of them, we form two subsets. Within each subset, regions are identical in all aspects; and therefore, it is like if there were only two economies in the model, call them $i$ and $j$. Areas $i$ and $j$ possess the same production and preference structure; they only differ in the endowment of natural riches and population density, characteristics that are taken as exogenous.

To formalize this last assumption, we can follow Ciccone and Hall (1996), and think that people differ in their preferences over the degree of agglomeration related to the place where they are located. We can also assume, as in Mansoorian and Myers (1993), that individuals derive a non-pecuniary benefit from living in a certain place; for example, individuals have a preference for a particular region for cultural or nationalistic reasons.

The complete lack of labor mobility is an extreme scenario that we adopt for simplicity. However, as will become clear, the only thing that we need for the model results to go through is that capital and labor do not move together in the same direction. We provide some evidence in the discussion section that justifies this, and interpret the finding as a consequence of agglomeration differences between resource abundant and resource scarce regions.

\footnotetext{
${ }^{8}$ We focus on a closed economy even though, in reality, labor and capital can move across nations. Inflows from abroad, however, have a relatively small impact on total input-stock changes. On one hand, net capital flows across countries are small - this is the well known Feldstein-Horioka puzzle. Immigration flows, on the other hand, are also relatively low; the annual inflow of migrants in the European Union, for example, represents about 3 per 1000 inhabitants, according to Eurostat.
} 


\subsection{Production}

The production function is taken from Ciccone and Hall (1996). In each area, there exist a large number of profit-maximizing firms of mass one that rent capital $(K)$ and labor $(L)$ to produce output $(Y)$. Focusing on area $i$, the production function is given by:

$$
Y_{i}=a_{i} A\left[\left(\frac{L_{i}}{a_{i}}\right)^{\beta}\left(\frac{K_{i}}{a_{i}}\right)^{1-\beta}\right]^{\alpha}\left(\frac{Y_{i}}{a_{i}}\right)^{\frac{\lambda-1}{\lambda}} ;
$$

where the parameters $\alpha, \beta \in(0,1)$, and $\lambda>1 ; a_{i}$ is the land area of region $i$, and $A$ is the Hicks neutral technology level of the nation. The variable $L_{i}$ is exogenous, whereas $K_{i}$ is endogenous. The elasticity $\alpha$ is less than one by the amount of the share of land on factor payments. Agglomeration is represented by the measure output per hectare $Y_{i} / a_{i}$, and weighted by the constant elasticity $(\lambda-1) / \lambda$. Its presence in the RHS of the production function implies the existence of agglomeration economies, taken as exogenous by firms.

From equation (1), once the externality is internalized, we obtain

$$
\frac{Y_{i}}{a_{i}}=A^{\lambda}\left[\left(\frac{L_{i}}{a_{i}}\right)^{\beta}\left(\frac{K_{i}}{a_{i}}\right)^{1-\beta}\right]^{\alpha \lambda} .
$$

The total output elasticity with respect to labor and capital depends on both the congestion parameter $\alpha$ and the agglomeration externality parameter $\lambda$. If $\alpha \lambda$ is greater than one, the externality effect dominates congestion.

Unlike labor, capital moves perfectly across regions, so that its rental price $(r)$ is equalized. We can use the first order condition of the firm's problem to get the following demand function for capital:

$$
\frac{K_{i}}{Y_{i}}=\frac{\alpha(1-\beta)}{r_{t}+\tau_{i}}
$$

where $\tau_{i}$ is the tax rate on capital in region $i$. Thus, we get

$$
\frac{Y_{i}}{a_{i}}=\left[\frac{\alpha(1-\beta)}{r_{t}+\tau_{i}}\right]^{\frac{\alpha \lambda(1-\beta)}{1-\alpha \lambda(1-\beta)}} A^{\frac{\lambda}{1-(1-\beta) \alpha \lambda}}\left(\frac{L_{i}}{a_{i}}\right)^{\frac{\alpha \lambda \beta}{1-\alpha \lambda(1-\beta)}} .
$$

\subsection{Regional Governments}

It is straightforward that, in our setup, a benevolent policymaker that chooses tax rates in a fiscally centralized nation will always generate gains in output as a consequence of 
the discovery of natural resources. Given this, our analysis focuses exclusively on the fiscal decentralization case.

The public sector taxes capital and uses the region's natural input endowment to provide a public consumption good to the economy. Its problem reduces to choosing the tax rate $\left(\tau_{i}\right)$ that maximizes the current utility level of a representative individual. ${ }^{9}$

More specifically, the government in region $i$ solves:

$$
\max _{\tau_{i}}\left\{U_{i}=\ln \frac{C_{i}}{L_{i}}+\gamma \ln \frac{G_{i}}{L_{i}}\right\}, \gamma>0,
$$

subject to

$$
\begin{gathered}
Y_{i}+Z_{i}=C_{i}+G_{i}, \\
G_{i}=\tau_{i} K_{i}+Z_{i}
\end{gathered}
$$

where $C_{i}$ and $G_{i}$ are the amounts of the private and the public consumption goods, respectively; $Z_{i}$ is the value of natural riches net of extraction costs. ${ }^{10}$

There are a number of implicit assumptions in expressions (6) and (7). In particular, we suppose that both consumption goods are produced with the same technology. Also, natural riches can be converted into the public good at zero cost.

The government takes as given the interest rate $r$ as well as the firms' demand function (3), and internalizes the external effect of agglomeration. As a consequence, output is given by equation (4) from the government's viewpoint. With those assumptions, the first order condition to the above problem obtains

$$
\gamma \frac{C_{i}}{G_{i}}=\left[1+\frac{\lambda}{1-\alpha \lambda(1-\beta)}\right]
$$

Equation (8) is a Ramsey-Keynes condition; the marginal rate of substitution (LHS) is equalized to the marginal rate of transformation (RHS). It says that the optimal relative allocation to the private good increases with the strength of the agglomeration externality. The reason is that the amount of private good to which you need to renounce for each additional unit of the public good increases with $\lambda$. It also implies

\footnotetext{
${ }^{9}$ The government's goal can be expressed in several forms (e.g., see Wilson 1999). A benevolent policymaker is just one of them that we adopt for simplicity. While the chosen objective function is critical for understanding, for example, whether tax competition can discipline governments, it does not play a big role in the current context.

${ }^{10}$ The assumption that $Z$ accrues to the region is a consequence of operating under a fiscally decentralized economy.
} 
that the private-to-public good ratio decreases with the weight of the public good in the utility function.

Substituting conditions (6) and (7) into (8), we can write the optimal capital tax rate as

$$
\begin{aligned}
\tau_{i} & =0 \quad \text { if } Z_{i}>\frac{r K_{i}}{\alpha(1-\beta) \phi} \\
\tau_{i} & =\frac{r-\alpha(1-\beta) \phi \frac{Z_{i}}{K_{i}}}{\alpha(1-\beta)(1+\phi)-1} \quad \text { otherwise, }
\end{aligned}
$$

with

$$
\phi=\frac{1}{\gamma}\left[1+\frac{\lambda}{1-\alpha \lambda(1-\beta)}\right] .
$$

If $Z_{i}$ is zero then the tax rate given by (9) is just a function of the interest rate

$$
Z_{i}=0 \quad \Longrightarrow \quad \tau_{i}=\frac{r}{\alpha(1-\beta)(1+\phi)-1}
$$

A higher $r$ implies a bigger tax rate charged by the government. ${ }^{11}$ The intuition comes from condition (8). In the absence of natural riches, a higher interest rate is associated with a larger ratio of private-to-public goods; however, since this ratio remains constant at the optimum, the tax rate must increase to produce additional $G$.

When the region owns natural resources, however, expression (9) defines $\tau_{i}$ as an implicit solution because $K_{i}$ is actually a function of $\tau_{i}$. In order to know how the tax rate reacts to changes in the variables and parameters that the region takes as exogenous, we can use expressions (3), (4) and (9) to get

$$
\frac{\left(r+\tau_{i}\right)^{\alpha \lambda(1-\beta)}}{\left[1-\frac{\alpha(1-\beta)(1+\phi)}{1+r / \tau_{i}}\right]^{1-\alpha \lambda(1-\beta)}}=\frac{\alpha(1-\beta)^{\alpha \lambda(1-\beta)} A^{\lambda}\left(\frac{L_{i}}{a_{i}}\right)^{\alpha \lambda \beta}}{\left(\phi Z_{i}\right)^{1-\alpha \lambda(1-\beta)}}
$$

This equality implicitly solves $\tau_{i}$ as a function of $r$ and region-specific characteristics.

The LHS of expression (12) equals $r^{\alpha \lambda(1-\beta)}$ when $\tau_{i}$ equals zero, and rises with $\tau_{i}$ if $\alpha \lambda(1-\beta)<1$ which is the case suggested by the calibration below. Hence, when the last inequality holds, the optimal value of $\tau_{i}$ is unique and decreases with the endowment $Z_{i}$. For a sufficiently large value of the natural endowment, the region can

\footnotetext{
${ }^{11}$ Although we take area $i$ 's perspective, note that result (11) holds also for area $j$, given that $Z_{j}=0$.
} 
fully finance public goods using natural riches, and then the optimal tax rate becomes zero. In particular, expression (12) says that

$$
Z_{i} \geq\left[\frac{\alpha(1-\beta)^{\alpha \lambda(1-\beta)} A^{\lambda}\left(\frac{L_{i}}{a_{i}}\right)^{\alpha \lambda \beta}}{r^{\alpha \lambda(1-\beta)} \phi^{1-\alpha \lambda(1-\beta)}}\right]^{\frac{1}{1-\alpha \lambda(1-\beta)}} \Longrightarrow \tau_{i}=0 .
$$

In expression (12), the effects of the agglomeration externality parameter and the interest rate are ambiguous. From equality (9), however, we can deduce that their direct impact on $\tau_{i}$ is clear: in (9), the tax rate decreases with $\lambda$ and rises with $r$. The ambiguity comes from general equilibrium effects that work through the physical capital stock $K_{i}$, and affect $\tau_{i}$ in the opposite direction. Notice that the interest rate is endogenous for the country as a whole, and therefore, the effect of $\lambda$ on $\tau_{i}$ also depends on $r$, even when $Z_{i}=0 .{ }^{12}$

\subsection{Equilibrium}

Governments choose taxes according to (9). The interest rate $r$ then moves until the capital market clears, that is, until

$$
K_{i}+K_{j}=K
$$

where $K$ is the nation's capital stock, which is taken as given. At that point, the whole economy is in equilibrium.

The stocks $K_{i}$ and $K_{j}$ need to be such that the returns to capital are equalized across economies. This non-arbitrage condition is the following:

$$
r=\alpha(1-\beta) \frac{Y_{i}}{K_{i}}-\tau_{i}=\alpha(1-\beta) \frac{Y_{j}}{K_{j}}-\tau_{j}
$$

Employing production function (2) and clearing condition (14), expression (15) can be rewritten as

$$
\left(\frac{L_{j}}{a_{j}}\right)^{\beta \alpha \lambda}\left(\frac{K-K_{i}}{a_{j}}\right)^{(1-\beta) \alpha \lambda-1}-\left(\frac{L_{i}}{a_{i}}\right)^{\beta \alpha \lambda}\left(\frac{K_{i}}{a_{i}}\right)^{(1-\beta) \alpha \lambda-1}=\frac{\tau_{j}-\tau_{i}}{\alpha(1-\beta) A^{\lambda}} .
$$

Expressions (15) and (16) allow obtaining $K_{i}$ as a function of the interest rate, the country's aggregate capital stock and regions' characteristics. We can easily deduce

\footnotetext{
${ }^{12}$ Later, through the calibration exercise, we observe that the indirect effects of $\lambda$ on $\tau_{i}$ dominate the direct ones, so that ultimately a greater agglomeration externality leads to higher tax rates.
} 
that, as the tax gap increases, there is a reallocation of capital from the economy that imposes a higher tax rate to the one that imposes a lower one.

An interesting case is the non-natural-endowment one. If $Z_{i}=Z_{j}=0$, tax rates are equalized across regions, ${ }^{13}$ and then the optimal capital stock is given by the following closed-form solution obtained using expression (16):

$$
K_{i}=\frac{K}{1+\left[\left(\frac{L_{j}}{L_{i}}\right)^{\beta \alpha \lambda}\left(\frac{a_{i}}{a_{j}}\right)^{\alpha \lambda-1}\right]^{\frac{1}{1-(1-\beta) \alpha \lambda}}} .
$$

Economy's $i$ capital stock depends on its relative labor allocation and relative land surface. Because labor and capital are complementary in production, a relatively larger labor endowment increases the capital stock. The effect of the relative land area, on the other hand, depends on whether the agglomeration externality effect dominates congestion. If it does $(\alpha \lambda>1)$, more land reduces the optimal capital stock because, ceteris paribus, there is less population density. The opposite is true if congestion dominates $(\alpha \lambda<1)$.

In absence of natural riches, it is also possible to derive a closed-form expression for the equilibrium interest rate. The production function (1), the expression for the interest rate (15), the solutions for the optimal tax rate (11), and the capital stock (17) deliver

$$
r=\left[\alpha(1-\beta)-\frac{1}{1+\phi}\right] A^{\lambda}\left[\frac{\left(\frac{L_{i}^{\beta \alpha \lambda}}{a_{i}^{\alpha \lambda-1}}\right)^{\frac{1}{1-(1-\beta) \alpha \lambda}}+\left(\frac{L_{j}^{\beta \alpha \lambda}}{a_{j}^{\alpha \lambda-1}}\right)^{\frac{1}{1-(1-\beta) \alpha \lambda}}}{K}\right]^{1-(1-\beta) \alpha \lambda} .
$$

Population density increases the equilibrium interest rate when the agglomeration effect dominates, because it causes a positive total factor productivity (TFP) effect in the economy.

The effect of $\lambda$ on $r$ in (18) is also positive. As before, we have the TFP effect of stronger agglomeration economies that tends to increase the interest rate. In addition, there is now a change in the returns to scale captured by the term $1-(1-\beta) \alpha \lambda$ that affects labor and capital. This second effect, however, works mainly through $K$; weaker diminishing returns to capital accumulation also contribute to raise the interest rate.

\footnotetext{
${ }^{13}$ Bucovetsky (1991) shows that in an asymmetric tax competition with population differences, the more populated region imposes higher tax rates. We extend his analysis by showing that an agglomeration externality can possibly correct for that, as we observe that in equilibrium tax rates are equal despite having population differences.
} 
It is not possible to find out analytically the exact impact of changes in the natural endowment on the country's income level. Regions that enjoy a natural resource discovery will reduce taxes, and attract capital; but whether this brings a gain or a loss for the nation is unclear. As a consequence, we carry out a quantitative exercise to dig deeper on this issue. We calibrate first the parameters, and then present the model predictions.

\subsection{Calibration}

We calibrate the model to the U.S. economy. Given that the share of natural resource rents in U.S. GDP is only about 0.86 percent - the value for 2009 according to World Bank (2011a) - we use the equilibrium in the non-natural-endowment case to perform this task; this considerably simplifies matters.

Parente and Prescott (2000) report that a share of capital of 0.25, a land share of 0.05 , and a labor share of 0.7 are consistent with the U.S. growth experience. We then assign values of 0.95 and 0.73 to $\alpha$ and $\beta$, respectively. To pick a number for the agglomeration externality, we recall results in Ciccone and Hall (1996). These authors estimate that $\alpha \lambda=1.04$; that is, doubling employment density results in a 4 percent increase in TFP. This gives a value of 1.1 to $\lambda$.

The productivity parameter $A$ in the production function, and the areas $a_{i}$ and $a_{j}$ are normalized to 1 . Initial agglomeration differences between resource abundant and resource scarce regions are proxied using Ciccone and Hall's (1996) agglomeration index. Their measure is simply the intensity of labor, human, and physical capital relative to physical space. Agglomeration is high when there is a large amount of labor and capital per square foot. Their estimated range for the 50 contiguous U.S. states goes from 1.1 in Montana, a resource rich state, to 1.67 in the District of Columbia, a resource poor area. Alaska, the less agglomerated and one of most resource rich states, is then not included in their analysis. In the absence of natural riches, population density and capital agglomeration are perfectly correlated in our model. Hence, we choose $L_{i}=1.1$ and $L_{j}=1.67$, which implies a relative agglomeration level $Y_{i} / Y_{j}$ of 0.64 when $Z_{i}=0$ in the benchmark scenario, very close to $L_{i} / L_{j}=0.66$.

The value of the aggregate capital stock $K$ is, in turn, picked so that the capitaloutput ratio at steady state for the whole economy equals 3. Finally, the parameter $\gamma$, that is, the weight of public goods in the utility function is calibrated to reproduce the 
share of the U.S. government in GDP, used as a proxy for the ratio $G /(C+G)$ in the model. In the last 30 years, U.S. government spending as a fraction of GDP has been between 20 to 30 percent, depending on the method used for measuring it. We choose an intermediate value of 25 percent, which implies that $\gamma$ equals 0.84 .

\subsection{Results}

We now suppose that there is a natural resource windfall in region $i$, and compute the equilibrium values of some key variables depending on the size of this shock. We consider a maximum value for $Z_{i}$ of 0.036 . This upper bound equals to 0.86 percent of the model-economy's GDP in the $Z=0$ scenario (consistent with the contribution of natural resources to U.S. GDP in 2009).

Figure 3 presents results for five different parameterizations. The first row gives the benchmark case described in the calibration section. The second row is obtained when the agglomeration externality parameter $\lambda$ rises to 2 . In this case, the value of $\gamma$ is also modified to maintain the share of the public good invariant, and then abstract from demand-side effects. In the third row, the densities of the two regions are interchanged, $L_{i} / a_{i}$ equals 1.67 and $L_{j} / a_{j}$ equals 1.1. In the fourth row, the labor share $\beta$ falls to 0.7 , and is equivalent to making differences in the capital-labor ratio less effective. Finally, row 5 shows results when the share of the public good in total income $G /(C+G)$ becomes $22 \%$, lower than the benchmark.

The two columns in figure 3 provide results for tax rates and income levels (vertical axes) as a function of the natural endowment variable $Z_{i}$ (horizontal axis). Recall that, by assumption, region $j$ does not own natural riches $\left(Z_{j}=0\right)$. More specifically, the LHS column gives results for the tax rates $\tau_{i}$ (taui, black line) and $\tau_{j}$ (tauj, grey line). The RHS column, in turn, shows the predicted values of income in region $j\left(Y_{j}\right.$, solid grey line), income plus natural resource endowment in region $i\left(Y_{i}+Z_{i}\right.$, black line) and income in the whole country $\left(Y+Z_{i}=Y_{i}+Y_{j}+Z_{i}\right.$, dashed black line).

The qualitative effects on tax rates and regional income are the same across rows. In particular, when $Z_{i}=Z_{j}=0$, tax rates in both regions coincide. As the natural endowment rises in $i$, this region reduces pressure on taxpayers. Region $j$ then responds in the opposite direction, rising its capital tax rate to be able to finance public goods, thus amplifying the capital outflow. Income in region $j$ falls due to this, but increases in region $i$ because of both the capital inflow and the natural resource discovery. 
Figure 3: Tax Rates (left) and Relative Output Levels (Right) Predicted by Model
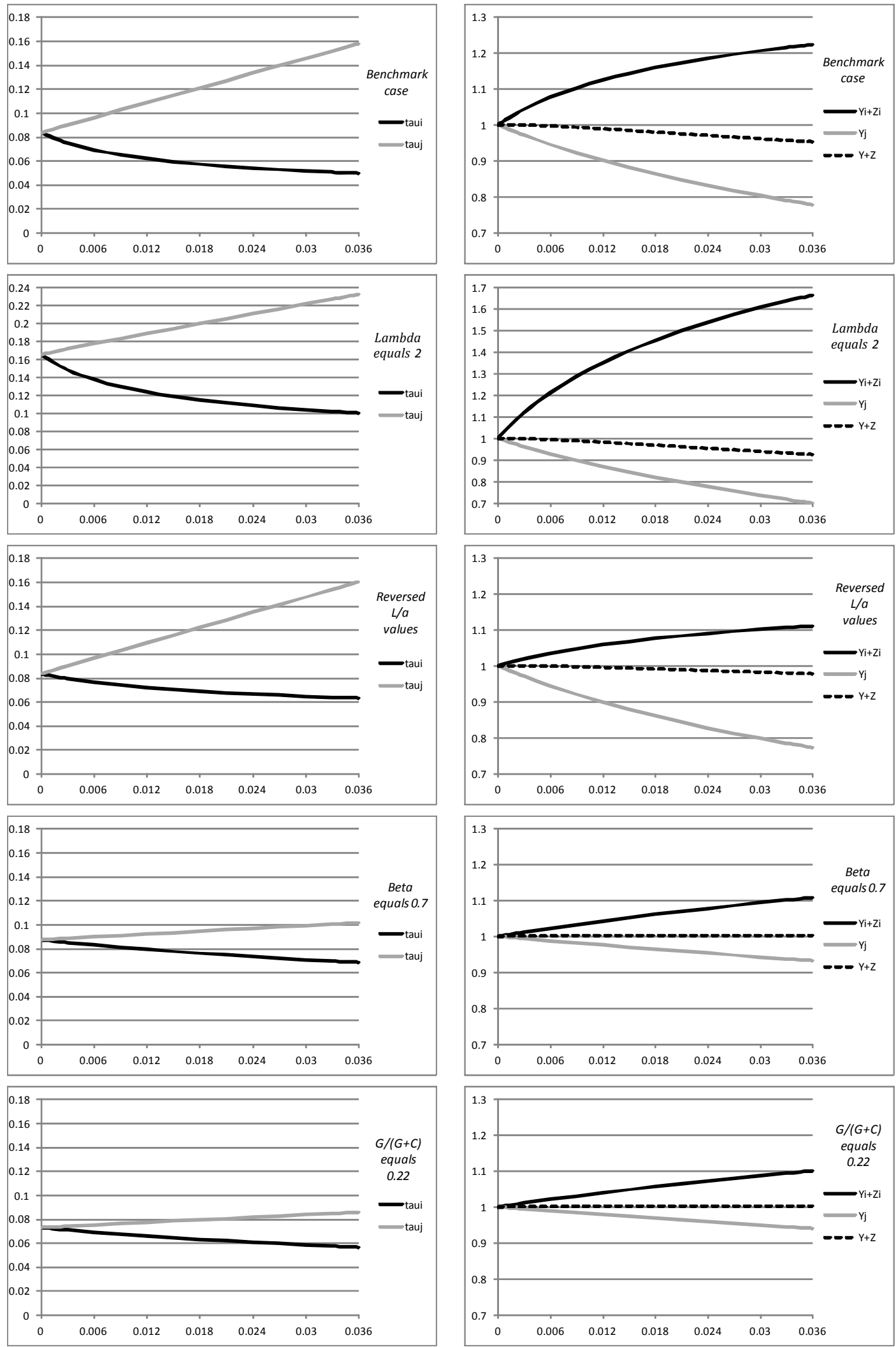
Quantitative findings and the effect on the nation's total income are, however, different across scenarios. Look at the dashed line in the RHS panels. In the benchmark economy (first row), the country's income falls as $Z_{i}$ increases. As capital moves away from the resource poor region, the economy gets as well away from the fully-flexible optimal capital-labor ratios; recall that diminishing marginal returns makes optimal to equalize capital-labor ratios across regions. The resource windfall moves the economy further away from that outcome, increasing the degree of inefficiency, and reducing country-wide output.

Agglomeration economies amplify the effect of input reallocations on output production. As a result, a larger agglomeration externality parameter contributes to make the decrease in income larger as $Z_{i}$ rises (see row two in figure 3). If labor followed capital towards resource abundant regions, the agglomeration externality would cause all labor and capital to move to region $i$ as soon as new natural riches are discovered, increasing the nation's welfare level. However, when labor is sufficiently immobile or moves in a different direction than capital, the externality is de facto not able to induce increasing returns; as a consequence, only a fraction of capital is reallocated, and then the externality serves to generate a stronger effect on tax rates and total income.

This effect of $\lambda$ on the tax rates can be seen in expression (9). For any natural stock, the optimal tax rate in both regions rises with $\lambda$ because so does the interest rate due to the TFP and diminishing-returns effects, as explained above after expression (18). We could say that governments tax the extra output from the agglomeration externality at a higher rate. ${ }^{14}$ On top of that, competition to attract capital becomes fiercer; equation (9) implies that the impact of a larger $Z_{i}$ on $\tau_{i}$ goes up, in absolute terms, with $\lambda$ (that is, $\left.\partial^{2} \tau_{i} / \partial Z_{i} \partial \lambda<0\right)$.

Row three presents results for the case where the resource rich region is more densely populated than the resource poor area; the opposite to what we observe in reality. Now, the negative effect on total income is weaker. The reason is again given by expression (9): as $K_{i}$ rises, an increase in $Z_{i}$ induces a smaller variation in the tax rate $\tau_{i}$; as a result, capital flows less and the effects on income become weaker. This is precisely the effect of a higher density in the region that enjoys the increase in $Z$, because the higher population density increases its initial capital stock; when the region is relatively richer, it has less incentives to attract capital. Another reason relates to the

\footnotetext{
${ }^{14}$ This is consistent with previous studies on tax competition and agglomeration; see Borck and Pfluger 2006.
} 
link between agglomeration and productivity as pointed by Ciccone and Hall (1996). Any movement of capital from the agglomerated region to the non-agglomerated one causes output loss, since the same unit of capital can produce more in the agglomerated region than in the non-agglomerated one. Switching densities between the resource rich and poor areas mitigates this effect. This, in turn, indicates that higher density in the resource poor region amplifies the negative effects.

Rows four and five in figure 3 represent two cases in which income levels in the country do not fall with natural riches. The first one (fourth row) is when the labor share is sufficiently low. This makes labor rigidities less important and in turn mitigates the negative effects derived from the increasing differences in the capital-labor ratios, because the weight of the labor input in production falls. In the case of $\beta=0.7$, the effect of a change in $Z$ on economy-wide output is negligible. We find the same effect in row five, which gives results when the share of pubic goods in total consumption falls to $22 \%$. A smaller government needs less taxes to finance itself and reacts less to changes in the natural endowment. In both cases, the ultimate reason for the lack of a negative impact on total income is that the tax rates in both regions do not react as much to changes in $Z$.

\subsection{Discussion}

The theory that we explored shows that a natural resource windfall can harm a country's GDP due to fiscal decentralization. This effect is amplified by agglomeration economies and a larger density in resource rich areas. A larger share of public-goods consumption in GDP also contributes to strengthen the negative impact.

Two main assumptions deliver these results: first, states employ taxes to attract capital from other parts of the country; second, labor does not fully follow capital when capital moves. Next, we assess the validity of these assumptions.

Regarding the first one, there are certainly other forms of tax competition, and other ways to attract capital such as public infrastructure provision. The emphasis on capital tax competition is made for simplicity, and because of its relative importance; this is shown, for example, by Newman and Sullivan (1988) and Wilson and Wildasin (2004) in their empirical and theoretical surveys, respectively. What is key is that there is evidence that supports that better-endowed areas compete more aggressively and drain capital from their poorly endowed counterparts, like for example the evidence 
provided by Cai and Treisman (2005) for post-communist Russia, and Raveh (2012) for U.S. states.

Implicit in the above assumption is that inter-regional tax competition in the model is independent of the country's level of institutional quality. Some scholars, like Qian and Roland (1998), argue that fiscal decentralization disciplines regional governments, in the sense that it creates inter-regional competition over factors that punishes inefficient policy behavior with capital flight. This implies that inter-regional tax competition arises regardless of the level of institutional quality; indeed, tax competition for factors among regions is observed in nations such as China and Russia that have relatively weak institutions, as Li et al. (2000) and Cai and Treisman (2005) show.

With respect to the second assumption, the evidence says that the degree of interregional labor mobility depends on the country being studied. Eichengreen (1993), for example, estimates an elasticity of inter-regional migration with respect to the ratio of local wages to the national average that is 25 times higher in the U.S. than in the U.K.; the difference with respect to Italy is even larger. As Decressin and Fatas (1995) argue, the result is that regional labor adjustments in Europe occur through a fall in the participation rate instead of through outwards migration.

Nevertheless, the only requirement that we need for our results to go through (in addition to having the standard framework of diminishing marginal productivities) is that capital and labor do not move together towards low-agglomerated resourceabundant regions. In order to offer evidence that supports it, we look at the relationship between changes in each of the two inputs and natural resources. More specifically, we look at the partial correlation between the growth in population density and the initial GDP share of the primary sector, and between the growth in capital investment and the initial GDP share of the primary sector, controlling for the initial values of the non-natural input measures (to account for potential convergence effects).

Figure 4 gives results for the U.S.; for other countries, findings are qualitatively the same, and relegated to appendix 1. The top panel depicts the residuals from regressing the average annual growth from 1977 to 2008 of population density on population density in 1977 against the residuals of the GDP share of the primary sector in 1977 on population density in 1977 . Notice that the slope of the regression line gives the coefficient on the natural input measure in the regression of population density growth on natural resources and initial population density. This slope is negative and strongly 
Figure 4: Partial correlation of average annual input growth and initial natural resources, US Economy, 1977-2008
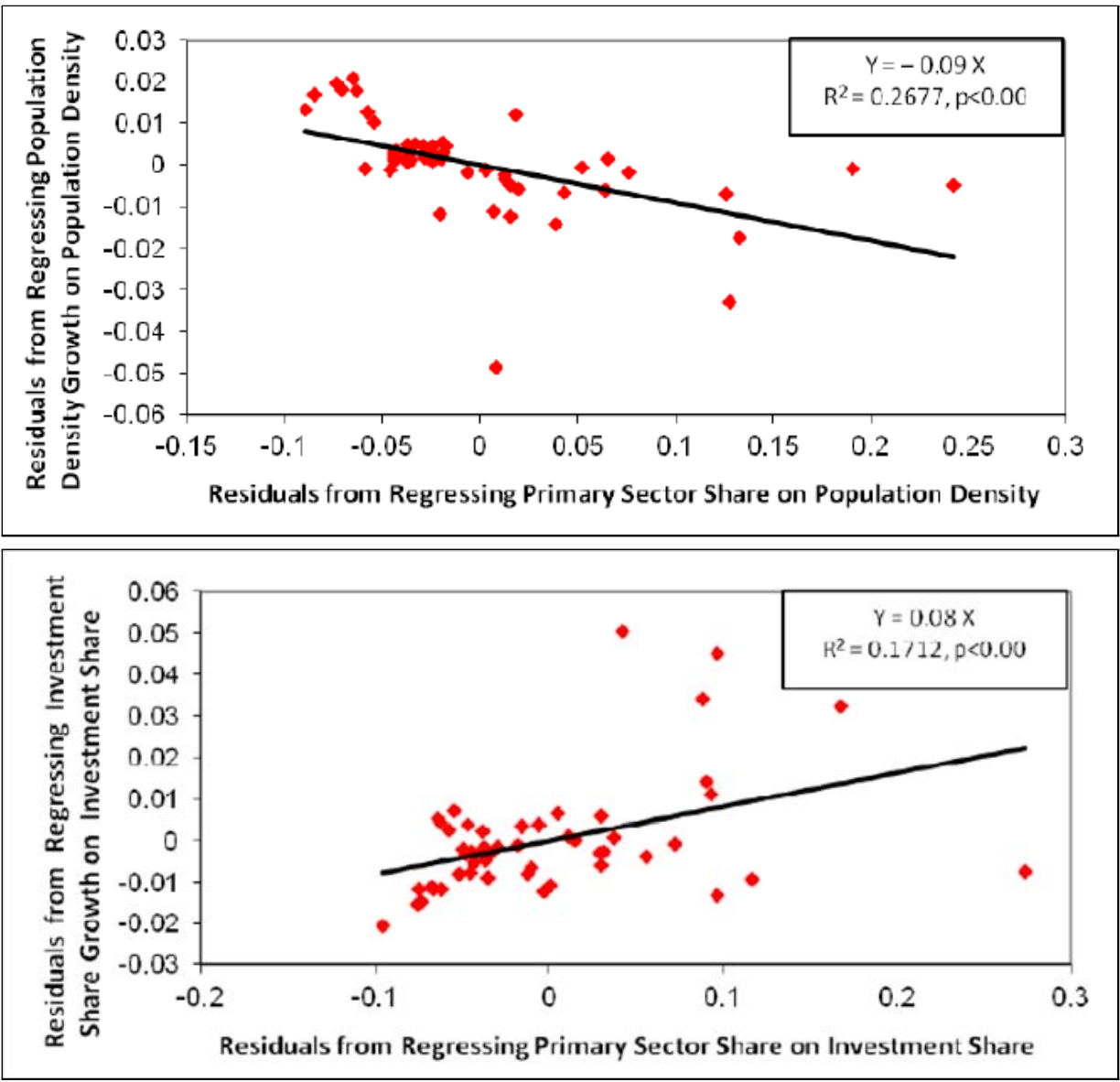
significant; this gives some indication that population in resource abundant regions grows more slowly.

The bottom chart in Figure 4 undertakes the same analysis for the capital input. For the same time period, the panel depicts the residuals from regressing the growth of the GDP share of investment on the initial GDP share of investment against the residuals of the initial GDP share of the primary sector on the initial GDP share of investment. ${ }^{15}$ Now results are opposite: resource abundant regions attract on average more capital. That is, investment increases faster but population grows more slowly in regions with more resources. This is obtained while controlling for possible transitional effects caused by relatively low initial levels, and also for investment induced by output changes.

Anecdotal evidence on unemployment also points out to the same conclusion that labor and capital movements are not driven by the same forces. If labor moved following only job opportunities, unemployment rates should be equalized across economies. However, oil rich areas such as Aberdeen in the U.K., and North Dakota and North Slope Borough (Alaska) in the U.S. enjoy much lower unemployment rates than their respective national economies. According to the Office of National Statistics, the unemployment rate in Aberdeen on July 2010 was 2.2\%, compared to 8.4\% for Scotland. The above two U.S. areas display similar patters: unemployment rates on February/March 2012 in North Dakota and North Slope Borough were 3.1\% and 5.5\%, respectively; much lower than the $8.3 \%$ of the U.S..

All these pieces of evidence provide support to the assumption that labor does not follow capital at least towards less agglomerated and more isolated areas where natural riches are mostly located. We could say that whereas capital only searches for financial returns, labor shows a preference for more agglomerated areas.

\section{Empirical Evidence}

This section provides empirical support for the main hypothesis of the paper; namely, that fiscally decentralized economies are more vulnerable to the growth curse of natural resources. It also tries to test the amplification mechanisms to which theory has pointed

\footnotetext{
${ }^{15}$ For the investment measure, we follow Papyrakis and Gerlagh (2007) and proxy it employing the GDP share of industrial machinery production, because BEA does not publish investment data at the state level.
} 
out. Given that the fundamental findings on the curse are rooted in the seminal work of Sachs and Warner (1997), subsection 3.1 tests our hypothesis using their database and cross-sectional methodology. Later, subsection 3.2 departs from Sachs and Warner and undertakes panel estimations using an extended sample of countries and years covered. Finally, in subsection 3.3, we undertake various robustness checks.

A detailed description of all variables and their sources are given in appendix 2 . Appendix 3 provides the nations included in each of the samples. Appendix 4 presents descriptive statistics for all variables employed in the paper.

\subsection{Cross-Section Tests}

We first employ Sachs and Warner's (1997) data, variables, and cross-sectional estimation methodology. Because of limitations in the fiscal decentralization data, the original sample reduces to a cross-section of 52 countries that covers the period of 1970-1990.

We test the following model:

$$
\hat{y}_{i}=\alpha_{0}+\alpha_{1} X_{i}+\varepsilon_{i}
$$

where $i$ represents the country; $\hat{y}$ is average annual growth in real per capita GDP during the interval 1970-1990; $X$ is a vector of controls that includes resource share, initial income, openness, investment, institutional quality, ethnicity, terms of trade, education, fiscal decentralization, interactions terms of the natural resource share with ethnicity, institutional quality and fiscal decentralization, and a dummy for landlocked economies; $\varepsilon_{i}$ is the disturbance.

We start using the GDP share of mineral output in 1970 as the resource share proxy. As for the fiscal decentralization measure, we follow Davoodi and Zou (1998), Oates (1985, 1993) and Zhang and Zou (1998), and employ the World Bank's Fiscal Decentralization Indicators, which are based on data from the International Monetary Fund's Government Finance Statistics. ${ }^{16}$ Since the World Bank provides several of those measures, we use the one that most closely resembles the model's notion of fiscal

\footnotetext{
${ }^{16}$ In terms of coverage, indicators are only provided for countries that report expenditures at both the national and sub-national levels. Nonetheless, as reported by the World Bank, this coverage reflects a lack of reported data rather than few countries with local and provincial governments; also, this should not necessarily reflect differences in the degree of fiscal decentralization between countries included in the sample and those that are not - the sample ranges from highly decentralized countries to highly centralized ones.
} 
decentralization, which is the degree to which sub-national governments fund their expenditures through their own revenue sources (Vertical Imbalance). This indicator is a number between 0 and 100; the closer it is to 100 the more independent sub-national governments are in terms of relying on their own revenue sources for their expenditures, implying that the country as a whole is more fiscally decentralized. ${ }^{17}$

Results appear in table 1. Regression 1 replicates Sachs and Warner's (1997) analysis with the addition of Mehlum et al.'s (2006) interaction term of institutional quality and resources, as well as Hodler's (2004) interaction term of fractionalization and resources. Results on convergence, resource abundance, openness, investment, institutional quality, ethnicity, terms of trade, education, and landlocked economies, replicate those presented in previous studies in terms of signs and occasionally significance; however, previous results on the interaction terms are less robust to our sample. ${ }^{18}$

In regression 2 we add the fiscal decentralization measure; results do not change. In regression 3 we add the interaction term between the resource share proxy and fiscal decentralization; its coefficient is negative and significant which confirms our main hypothesis by showing that the negative growth effect of resources is transmitted through the decentralization channel. In addition, despite being non-significant, the coefficient on the resource share proxy becomes positive. Results do not change if other resource measures used by Sachs and Warner, like the share of primary exports in total exports or out of total GDP, are adopted. ${ }^{19}$

To further strengthen our claim, let us try to offer additional evidence in favor of one of the crucial mechanisms that drive the model prediction that fiscally decentralized nations do not benefit from resource windfalls: inter-regional differences in agglomeration levels. Recall that the theory suggests that, when these differences rise, the amplifying effects produced by agglomeration economies become stronger. In addition, because labor mobility and agglomeration levels are positively correlated, as

\footnotetext{
${ }^{17}$ Given that Sachs and Warner's (1997) analysis starts at 1970, the fiscal decentralization measure collected for each country is the one closest to 1970, up to 1975 (to mitigate endogeneity concerns), so that countries that do not have such a measure available up to 1975 are not included in the sample. This limits the coverage of our cross-sectional sample to 52 countries.

${ }^{18}$ Even when they enter the model separately, without including the fiscal decentralization index, Mehlum et al.'s (2006) and Hodler's (2004) results do not hold (results available from the authors). The reason can be our limited sample, or the use of an output-based resource measure - as opposed to an export-based one used in their studies.

${ }^{19}$ We present results using the GDP share of mineral output because it provides a larger sample. Nonetheless, we explicitly show with panel data that results hold using an exports-based measure in the following sub-section.
} 
Puga (1999) for example argues, the test can be seen as well as a test of the labor market channel; higher differences in agglomeration will mean that capital and labor move less in the same direction.

In particular, we construct an agglomeration index based only on population density, which is more closely related to labor movements. This measure divides each country's total non-agglomerated area by its total area (both in square kilometers); where the calculation of non-agglomerated areas follows the definition of non-agglomeration as given by the United Nations, on per-country basis. A higher value is interpreted as an indication of agglomeration differences and a stronger potential impact of the labor market channel. ${ }^{20}$

The model prediction is that decentralized economies with a higher index are more vulnerable to the growth curse. We multiply the initially used fiscal decentralization measure and the above index, and refer to the updated index as potential vulnerability. Results are presented in regression 5, and confirm those presented in regression 3. This provides some validation to the underlying mechanism, implying that resource endowments hurt decentralized economies through the labor mobility and non-agglomeration channels.

One key concern in the resource curse literature is the potential endogeneity of Sachs and Warner's resource abundance measure (Van der Ploeg 2011). To address this issue in the cross-sectional framework, we follow Brunnschweiler and Bulte (2008) and Arezki and Van der Ploeg (2011), and use the World Bank's (2006) measure of natural capital: the total stock of sub-soil assets, timber, non-timber forest resources, protected areas, cropland, and pastureland. This stock variable is arguably more exogenous to growth than Sachs and Warner's flow variables (specifically, the one used in the regressions of table 1), because it captures an economy's amount of proven natural reserves rather than its capacity to produce or export them.

In table 2 we reproduce the regressions presented in table 1, but using the GDP share of natural capital in 2000 as the resource share proxy. ${ }^{21}$ As we can see in regression 7, initial results are consistent with Brunnschweiler and Bulte's (2008), Mehlum et

\footnotetext{
${ }^{20}$ Importantly, the sample shows a weak relationship between this agglomeration measure and economic growth $(\rho=0.00, p<0.876)$, so that it is not necessarily the case that developed countries present a lower value, which mitigates endogeneity related concerns.

${ }^{21}$ The World Bank also provides this measure for 1994 and 2005. Results do not change qualitatively in case either of them is used. The 2000 one is preferred because it provides the largest sample size of 51 countries.
} 
al.'s (2006) and Hodler's (2004), in terms of sign and significance. The addition of fiscal decentralization in regression 8 does not alter the outcome. The key result is presented in regression 9, where the interaction term of fiscal decentralization and resource share is added; we observe that despite using this relatively more exogenous resource share measure, the coefficient on the interaction term remains negative and significant, further confirming the main hypothesis. Results hold as well in regression 12, when we adopt the previously discussed potential vulnerability measure.

The model implies that, in addition to agglomeration levels, the size of regional governments play a role as well: larger regional governments can potentially amplify the negative growth effect of natural resources. We test this prediction, by reproducing regression 12 under a different potential vulnerability measure. Thus, we construct a new variable labeled modified potential vulnerability, in which we multiply the level of fiscal decentralization (Vertical Imbalance) by the GDP share of general government final consumption expenditure in 1972. Here we are assuming that larger shares at the national level imply larger shares at the regional level. Regression 14 presents the results using the new proxy for the interaction variable. The interaction term not only remains strongly significant, but also increases in magnitude. This strengthens the empirical link to the model, and gives some indication that the size of regional governments may indeed be relevant for our hypothesis.

Fiscal decentralization can also suffer from endogeneity problems. Previous studies show that fiscal decentralization has several determinants, the key ones being land area, level of democracy, and level of income, each affecting fiscal decentralization positively. ${ }^{22}$ Thus fiscal decentralization may in fact be endogenous to growth through an unobserved development factor; consequently, the positive association between income and fiscal decentralization could be creating an upward bias. ${ }^{23}$ We address this concern by taking an IV approach. In particular, we use the abovementioned determinant, land area, as instrument for fiscal decentralization. Land area is based on geographic factors, and therefore, should be exogenous to growth.

To implement this we follow Wooldridge's (2002) approach to instrumentation of endogenous interaction terms. In the first stage, we predict fiscal decentralization using the instrument and the exogenous explanatory variables of the regression. We

\footnotetext{
${ }^{22}$ See Arzaghi and Henderson (2005), Oates (1972), Panizza (1999), and Treisman (2006).

${ }^{23}$ This implies that in the absence of such endogeneity bias the key result would only strengthen. We make an attempt at addressing this nevertheless.
} 
then interact the predicted variable with the natural resource share proxy and use it in the second stage of TSLS estimation. Results for the mineral output based resource share measure are presented in regressions 4 and 6 of table 1, and those for the natural capital based resource share measure are presented in regressions 10 and 13 of table 2 .

First stage results confirm the validity of the instrument, through the $F$-statistic. Second stage estimations, in turn, show that the key result remains: the coefficient on the interaction term of decentralization and resources is negative and significant in all cases.

\subsection{Panel Data Analyses}

The previous cross-sectional analyses, a la Sachs and Warner, raise several concerns. First, the time period covered is limited (1970-1990). Second, the sample covers merely 52 countries. Last, the cross-sectional estimation methodology potentially gives rise to both omitted variable and endogeneity biases (Van der Ploeg 2011). Departing from Sachs and Warner, we now employ an extended panel that covers the period 1972-2008 (in 9-year intervals) for 74 countries; ${ }^{24}$ the maximum number provided by the World Bank's Fiscal Decentralization Indicators. The use of this panel allows addressing the above concerns.

We estimate the following model:

$$
\hat{y}_{i t}=\beta_{0}+\beta_{1} X_{i t}+\varphi_{i}+\eta_{t}+\varepsilon_{i t}
$$

The variables $\hat{y}_{i t}, X_{i t}$ and $\varepsilon_{i t}$ are the same ones as in regression (19), for country $i$ at date $t$; the only difference is that we now do not include ethnicity and terms of trade as controls due to lack of data. The dummies $\varphi_{i}$ and $\eta_{t}$ represent country and time fixed effects that mitigate the potential omitted variable bias. All variables are measured in the initial year of the corresponding time interval to mitigate endogeneity concerns, and are expressed in deviations from period means so that time effects are cancelled. ${ }^{25}$

Not all the explanatory variables employed in the panel estimation are measured in the same way as in the cross-section analysis, due to data limitations. Nevertheless, all our measures are standard in the economic growth literature (see appendix 2). To

\footnotetext{
${ }^{24}$ This is an unbalanced panel, limited by data availability of the World Bank's Fiscal Decentralization Indicators. We use 9-year intervals to maximize sample size; longer time intervals decrease it significantly.

${ }^{25}$ This means that time fixed effects are implicitly controlled for in all the corresponding regressions; this methodology follows the one adopted by Caselli et al. (1996).
} 
measure resource share we employ the GDP share of primary rents; data is provided by the World Bank. ${ }^{26}$

Results appear in regressions 15 to 17 of table 3 . In all of them, results on convergence, openness, investment, institutional quality, education, and decentralization are similar in sign, and occasionally in significance to previous findings with cross-section estimation. Regressions 15 and 16 show a non-significant coefficient on resources when fixed effects are included, consistent with the findings of Manzano and Rigobon (2001). The interaction of resources with institutional quality also appears as non-significant. Interestingly, regression 17 shows that our main result - a negative and significant coefficient on the interaction term between fiscal decentralization and resource share holds in this case as well.

To address the concern over the potential endogeneity of the fiscal decentralization measure, we once again employ an IV approach. In the fixed effects framework, we can no longer adopt a time-fixed instrument as land area; we need to consider a timevarying one. We then consider, as instrument, the average level of democracy in the 10 years preceding the corresponding time interval. On one hand, the democracy level is considered a key determinant of fiscal decentralization; on the other hand, the lagged average makes it relatively exogenous to growth in the following period.

The democracy measure is taken from the commonly used Polity IV Project. Estimation of the endogenous interaction term is done using the procedure discussed above. Results appear in regression 18 of table 3. First stage results validate the instrument through the $F$-statistic. The second stage shows that the main result holds, as the interaction term of interest remains negative and significant.

We also take an IV approach to address the potential endogeneity of the resource share proxy; thus, we instrument it with the GDP share of mineral rents in $t-1 .^{27}$ We view this measure as a suitable IV, because it is highly correlated with our proxy $(\rho=0.9)$, and relatively exogenous to growth. Its exogeneity can be justified as follows: first, mineral rents are not dependent on an economy's capability to export, thus making it less correlated with development and growth; second, mineral rents in developing economies are usually extracted by multi-national firms that bring their own technology and production factors, making these rents relatively independent of

\footnotetext{
${ }^{26}$ Rents are computed as unit rents times production, where a unit rent is the unit price less unit cost (each computed by the World Bank).

${ }^{27}$ Mineral resources include: oil, natural gas, minerals, and coal.
} 
unobserved development indicators; last, the lagged value is arguably more exogenous to growth in the following period.

Estimation of the endogenous interaction terms is carried out using the previously described procedure. Results are reported in regression 19 of table 3. In this regression, both fiscal decentralization and resource share are instrumented. Again, first stage results validate both instruments, and the second stage confirms our main result.

\subsection{Additional Robustness Checks}

Regressions 20 to 24 in table 3, and table 4, contain further robustness tests of our main hypothesis. Using the panel data, we begin by considering an exports-based resource measure widely used in the resource curse literature: Sachs and Warner's GDP share of primary exports. Regressions 20 to 24 reproduce regressions 15 to 19 using the exports-based measure. Despite the reduced country coverage (70 compared to the previous 74), results on all variables, including our interaction term, are similar in sign and significance. In addition, the inclusion of the interaction term reduces the effect of resources on growth by an order of magnitude as it did before.

We use the same IVs as in regressions 18 and 19. We note that the GDP share of mineral rents in $t-1$ is also highly correlated with the exports-based measure ( $\rho=0.74)$, making it applicable in this case well. We follow the previously described procedure to estimate the endogenous interaction terms. Results are reported in regressions 23 and 24 of table 3 . Note that in regression 24, both fiscal decentralization and resource share are instrumented. Again, first stage results validate both instruments, and the second stage confirms our main result.

Let us now test the hypothesis using a different fiscal decentralization measure, and in particular, the Kearney Decentralization Index (Arzaghi and Henderson 2005). Although there are several available decentralization indices, we adopt this one because of its larger time and country coverage: the index is available for 42 developing and developed countries over the years 1965-1995. The Kearney measure is a comprehensive index that covers nine distinct dimensions of fiscal decentralization. We adopt one of them: the Revenue Raising Authority dimension; it measures sub-national governments' formal authority to raise their own revenue through taxation, which resembles the model's notion of decentralization more closely. ${ }^{28}$ Regressions 25 through 29 in

\footnotetext{
${ }^{28}$ This component of the index assigns each country a number between zero and four, with four
} 
table 4 replicate regressions 15 to 19 using the Kearney measure and a panel that covers the period of 1965-2000 with 5-year intervals. ${ }^{29}$ We follow the same previously described procedures with the TSLS estimations. The new regressions show similar results to previous estimations, the only difference is a relatively higher magnitude for the interaction term. Our main result, therefore, seems to be robust to different decentralization measures.

One could argue that democracy is not a strong instrument for fiscal decentralization because it is correlated with income. Above, we dealt with this by employing lagged values of the democracy variable that should suffer less from this criticism. Nevertheless, we now test the cross-sectional version of our panel to be able to employ the logarithm of land area as an instrument for fiscal decentralization, rather than democracy. More specifically, we extend the previously used Sachs and Warner's cross-sectional sample to 2008, use the logarithm of land area as IV for fiscal decentralization, and employ the previously discussed natural capital measure as the resource share proxy. Regression 11 gives the outcome of this exercise for the period of 19702008. Our main finding is once again confirmed. Although not presented, similar results arise when the time interval that goes from 1990 to 2008 is used instead.

An additional concern might be that we test the hypothesis using Barro-type growth regressions; we could have worked with level regressions instead, in the spirit of Hall and Jones (1999) and Acemoglu et al. (2001). However, following the reasoning of Mehlum et al. (2006), undertaking level regressions requires using different resource share measures, since our measures are normalized by GDP. Notice that, ceteris paribus, countries with high GDP may appear as resource scarce, while countries with low GDP may appear resource abundant. Controlling for initial income corrects for that; yet, doing so while having income at the end of the period as the dependent variable is clearly equivalent to undertaking a growth regression.

\section{Conclusion}

The question of why resource endowments lead to divergent outcomes continues to attract much interest among economists. This paper has presented a novel answer to

having the highest level of revenue raising autonomy and zero the least.

${ }^{29}$ We adopt 5 -year intervals in this case, again to maximize the sample size - notice that the index is available in 5-year intervals as well. Nonetheless, results do not change qualitatively if 10-year intervals are adopted instead. 
that question; the hypothesis is that countries with a high degree of fiscal decentralization are more vulnerable to the natural resource curse. The new angle we have proposed implies that the paper also contributes to understanding the effects of fiscal decentralization on economic growth. Another contribution has been to point to a new potentially important source of factor misallocation: differences between capital and labor regarding the forces that drive their movement.

More specifically, we have explored a theory that suggests a simple mechanism for the occurrence of a natural resource curse in fiscally decentralized countries. In these economies, natural riches give the region in which they are located an advantage in the inter-regional competition over capital. This means that capital flows from resource poor areas to regions that experience natural resource windfalls. Labor seems to be, however, reluctant to follow capital towards low-agglomerated resource-rich regions. As a consequence a resource boom increases regional differences in the capital-labor ratio. Given diminishing marginal productivities, this inefficient factor reallocation can potentially drop total output in the nation. The theoretical analysis has shown that the negative effect amplifies with greater population densities in resource poor regions, larger regional governments, and a more significant agglomeration externality.

The main hypothesis - that countries with a high degree of fiscal decentralization are more vulnerable to the natural resource curse - and other key predictions of the model, have been empirically tested and confirmed. First, we used the original Sachs and Warner's (1997) data set and method; then, an extended panel, in conjunction with the World Bank's Fiscal Decentralization Indicators. Finally, we have shown that results are robust to different resource abundance and fiscal decentralization measures, as well as to different estimation techniques and time periods.

These insights carry certain policy implications for resource rich economies, especially in terms of emphasizing the importance of proper management of resources in fiscally decentralized nations, and the creation of incentives to improve labor mobility. Nonetheless, results may be sensitive to the specific periods and countries investigated. Future research should further test our results and analyze the mechanisms that drive them using different data sets as they become available. 


\section{References}

[1] Acemoglu, D., Johnson, S. and Robinson, J. A. (2001). The colonial origins of comparative development: an empirical investigation, American Economic Review 91, pp. 1369-401.

[2] Andersen, J., and Aslaksen, S. (2008). Constitutions and the resource curse, Journal of Development Economics 87(2), pp. 227-246.

[3] Arzaghi, M., and Henderson, J., (2005). Why Countries Are Fiscally Decentralizing? Journal of Public Economics 89, pp. 1157-1199.

[4] Barro, R., and Lee, J. (2010). A New Data Set of Education Attainment in the World, 1950-2010, NBER Working Paper No. 15902.

[5] Borck, R., and Pfluger, M. (2006). Agglomeration and tax competition. European Economic Review, 50, pp. 647-668.

[6] Brennan, G., and Buchanan, J. (1980). The Power to Tax: Analytical Foundations of a Fiscal Constitution, Cambridge University Press, New York.

[7] Brunnschweiler, C., N. and E.H. Bulte (2008). The natural resource curse revised and revisited: A tale of paradoxes and red herrings, Journal of Environmental Economics and Management 55(3), pp. 248-264.

[8] Bucovetsky, S. (1991). Asymmetric Tax Competition, Journal of Urban Economics, 30(2), pp. 167-181.

[9] Cai, H. and D. Treisman (2005). Does Competition for Capital Discipline Governments? Decentralization, Globalization, and Public Policy, American Economic Review 95(3), pp. 817-830.

[10] Caselli, F., Esquivel, G., and Lefort, F. (1996). Reopening the convergence debate: A new look at cross-country growth empirics, Journal of Economic Growth 1(3), pp. 363-389.

[11] Caselli, F., Morelli, M., and Rohner, D. (2012). The Geography of Inter-State Resource Wars, mimeo, London School of Economics.

[12] Ciccone, A., and Hall, R. (1996). Productivity and the density of economic activity, American Economic Review 86(1), pp. 54-70.

[13] Davoodi, H., and Zou,. H. (1998). Fiscal decentralization and economic growth: A cross country study, Journal of Urban Economics 43, pp. 244-257.

[14] Decressin, J., Fatas, A. (1995). Regional labor market dynamics in Europe, European Economic Review 39, pp. 1627-1655.

[15] Eichengreen, B. (1993). Labor markets and European monetary unification. In: Masson, P.R., Taylor, M.P. (Eds.), Policy Issues in the Operation of Currency Unions, Cambridge University Press, Cambridge, pp. 130-162.

[16] Frankel, J.A. (2010). The Natural Resource Curse: A Survey, NBER W.P. No. 15836. 
[17] Guillo, M.D. and F. Perez-Sebastian (2012). Neoclassical Growth and the Natural Resource Curse Puzzle, mimeo, University of Alicante.

[18] Gylfason, T., Herbertsson, T.T. and G. Zoega (1999). A mixed blessing: Natural resources and economic growth, Macroeconomic Dynamics 3, pp. 204-225.

[19] Gylfason, T. (2001). Natural resources, education, and economic development, European Economic Review 45, pp. 847-859.

[20] Hall, R. E. and Jones, C. I. (1999). Why do some countries produce so much more output per-worker than others? Quarterly Journal of Economics 114, pp. 83116.

[21] Hodler, R. (2006). The curse of natural resource in fractionalized countries, European Economic Review 50(6), pp. 1367-1386.

[22] Keen, M., and Marchand, M. (1997). Fiscal Competition and the Pattern of Public Spending, Journal of Public Economics 66(1), pp. 33-53.

[23] Lane, P. R. and Tornell, A. (1996). Power, growth and the voracity effect, Journal of Economic Growth 1, pp. 213-41.

[24] Li, S., Li, S., and Zhang, W. (2000). The Road to Capitalism: Competition and Institutional Change in China, Journal of Comparative Economics 28(2), pp. 269292.

[25] Mansoorian, A. and G.M. Myers (1993). Attachment to home and efficient purchases of population in a fiscal externality economy, Journal of Public Economics 52, pp. 117-132.

[26] Manzano, O. and R. Rigobon (2001). Resource Curse or Debt Overhang?, NBER Working Paper 8390.

[27] Marshall, A. (1920). Principles of Economics, 8th ed. (London: Macmillan and Co., Ltd.).

[28] Martinez-Vazquez, J., and McNab, R. (2003). Fiscal Decentralization and Economic Growth, World Development 31(9), pp. 1597-1616.

[29] Mehlum, H., Moene, K., and Torvik, R. (2006). Institutions and the resource curse, The Economic Journal 116, pp. 1-20

[30] Oates, W. (1972). Fiscal Federalism, New York, NY: Harcourt Brace Jovanovich, Academic Press.

[31] Oates, W. (1985). Searching for leviathan: An empirical analysis, American Economic Review 75, pp. 748-757.

[32] Oates, W. (1993). Fiscal decentralization and economic development, National Tax Journal XLVI, pp. 237-243.

[33] Panizza, U. (1999). On the Determinants of Fiscal Centralization: Theory and Evidence, Journal of Public Economics 74, pp. 97-139.

[34] Papyrakis, E., and Gerlagh, R. (2007). Resource Abundance and Economic Growth in the United States, European Economic Review 51, pp. 1011-1039. 
[35] Parente, S.L., and Prescott, E.C. (2000). Barriers to Riches, MIT Press, 2000.

[36] Puga, D. (1999). The Rise and Fall of Regional Inequalities, European Economic Review 43, pp. 303-334.

[37] Qian, Y., and Roland, G. (1998). Federalism and the Soft Budget Constraint, American Economic Review 88 (5), pp. 1143-1162.

[38] Raveh, O. (2012). Dutch Disease, Factor Mobility, and the Alberta Effect - The Case of Federations, mimeo, Hebrew University.

[39] Rodriguez, F., and Sachs, J.D. (1999). Why do resource-abundant economies grow more slowly?, Journal of Economic Growth 4, pp. 277-303.

[40] Sachs, J.D., and Warner, A.M. (1997). Fundamental sources of long-run growth, American Economic Review 87, pp. 184-188.

[41] Sachs, J.D., and Warner, A.M. (1999). The Big Push, Natural Resource Booms and Growth, Journal of Development Economics 59, pp. 43-76.

[42] Sachs, J.D., and Warner, A.M. (2001). Natural resources and economic development: The curse of natural resources, European Economic Review 45, pp. 827-838.

[43] Tiebout, C. (1956). A Pure Theory of Local Expenditures, Journal of Political Economy 64, pp. 416-24.

[44] Treisman, D. (2006). Explaining fiscal decentralization: geography, colonial history, economic development, and political institutions, Journal of Commonwealth and Comparative Politics 44(3).

[45] Van der ploeg, F. (2011) Natural Resource: Curse or Blessing?, Journal of Economic Literature 49(2), pp. 366-420.

[46] Wilson, J.D. (1999). Theories of Tax Competition, National Tax Journal 52, pp. 269-304.

[47] Wilson, J.D., and Wildasin, D.E. (2004). Capital Tax Competition: Bane or Boon, Journal of Public Economics 88(6), pp. 1065-1091.

[48] Wooldridge, J.M. (2002). Econometric Analysis of Cross Section and Panel Data. MIT Press.

[49] World Bank (2006). Where is the Wealth of Nations? Measuring Capital for the 21 Century, the World Bank, Washington D.C..

[50] World Bank (2011a). The Changing Wealth of Nations: Measuring Sustainable Development in the New Millennium, the World Bank, Washington D.C..

[51] World Bank (2011b). World Development Indicators, the World Bank, Washington D.C.

[52] Zhang, T., and Zou, H. (1998). Fiscal Decentralization, Public Spending, and Economic Growth in China, Journal of Public Economics 67, pp. 221-240.

[53] Zodrow, G., and Mieszkowski, Z. (1986). Pigou, tiebout, property taxation, and the underprovision of local public goods, Journal of Urban Economics 19, pp. 356-370. 
TABLE 1. Cross-country growth regressions, using the GDP share of mineral output as the resource share proxy [Cross-section, Sachs and Warner (1997) database, period: 1970-1990]

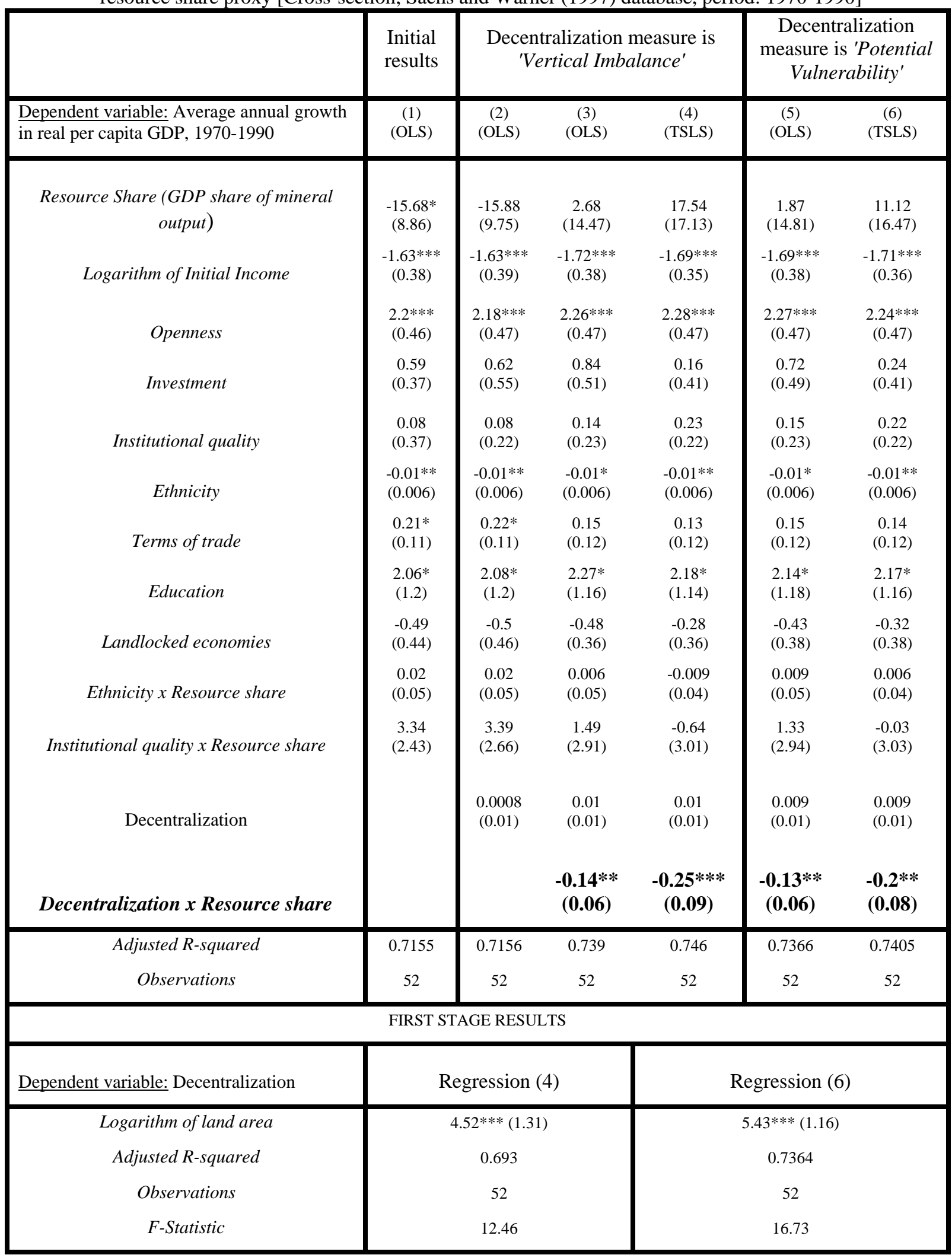

Standard errors are robust and appear in parentheses for independent variables. Superscripts correspond to a 10, 5 and 1\% level of significance. In the first stage results only the coefficient on the relevant instrument (land area) is reported, yet regressions include all variables reported in the second stage results. All regressions include an intercept. For description and source of variables as well as list of economies included in each regression see Appendices 2 and 3. For descriptive statistics see Appendix 4. 
TABLE 2. Cross-country growth regressions, using the GDP share of natural capital as the resource share proxy [Cross-section, Sachs and Warner (1997) database, period: 1970-1990, unless specified otherwise]

\begin{tabular}{|c|c|c|c|c|c|c|c|c|}
\hline & $\begin{array}{l}\text { Initial } \\
\text { results }\end{array}$ & \multicolumn{4}{|c|}{ Decentralization measure is 'Vertical Imbalance' } & \multicolumn{2}{|c|}{$\begin{array}{l}\text { Decentralization measure is } \\
\text { 'Potential Vulnerability' }\end{array}$} & $\begin{array}{c}\text { Decentralization } \\
\text { measure is the } \\
\text { 'Modified } \\
\text { Potential } \\
\text { Vulnerability' }\end{array}$ \\
\hline $\begin{array}{l}\text { Dependent variable: Average } \\
\text { annual growth in real per } \\
\text { capita GDP, 1970-1990 }\end{array}$ & $\begin{array}{l}(7) \\
\text { (OLS) }\end{array}$ & $\begin{array}{l}(8) \\
(\mathrm{OLS})\end{array}$ & $\begin{array}{l}(9) \\
\text { (OLS) }\end{array}$ & $\begin{array}{l}(10) \\
\text { (TSLS) }\end{array}$ & $\begin{array}{c}(11) \\
(\mathrm{TSLS}) \\
\text { Period: } \\
\text { 1970-2008 }\end{array}$ & $\begin{array}{l}(12) \\
\text { (OLS) }\end{array}$ & $\begin{array}{l}(13) \\
\text { (TSLS) }\end{array}$ & (14) \\
\hline $\begin{array}{c}\text { Resource Share (GDP share of } \\
\text { mineral output) }\end{array}$ & $\begin{array}{l}-24.92 \\
(28.58)\end{array}$ & $\begin{array}{l}-25.8 \\
(28.62)\end{array}$ & $\begin{array}{c}10.72 \\
(27.01)\end{array}$ & $\begin{array}{l}17.27 \\
(27.47)\end{array}$ & $\begin{array}{c}6.23 \\
(54.59)\end{array}$ & $\begin{array}{c}7.67 \\
(27.29)\end{array}$ & $\begin{array}{c}14.34 \\
(27.56)\end{array}$ & $\begin{array}{l}-7.66 \\
(22.8)\end{array}$ \\
\hline Logarithm of Initial Income & $\begin{array}{c}-1.78^{* * * *} \\
(0.34)\end{array}$ & $\begin{array}{c}-1.71^{* * *} \\
(0.36)\end{array}$ & $\begin{array}{l}-2.02 * * * \\
(0.38)\end{array}$ & $\begin{array}{c}-1.94^{* * * *} \\
(0.34)\end{array}$ & $\begin{array}{c}-2.22 * * * \\
(0.45)\end{array}$ & $\begin{array}{c}-1.99 * * * \\
(0.37)\end{array}$ & $\begin{array}{c}-1.94 * * * \\
(0.34)\end{array}$ & $\begin{array}{l}-2.1^{* * *} \\
(0.32)\end{array}$ \\
\hline Openness & $\begin{array}{c}2.79 * * * \\
(0.56)\end{array}$ & $\begin{array}{c}2.79 * * * \\
(0.55)\end{array}$ & $\begin{array}{c}2.81^{* * *} \\
(0.49)\end{array}$ & $\begin{array}{c}2.75^{* * *} \\
(0.49)\end{array}$ & $\begin{array}{c}5.09 * * * \\
(1.45)\end{array}$ & $\begin{array}{c}2.81 * * * \\
(0.49)\end{array}$ & $\begin{array}{c}2.75^{* * *} \\
(0.49)\end{array}$ & $\begin{array}{c}2.65 * * * \\
(0.48)\end{array}$ \\
\hline Investment & $\begin{array}{c}0.19 \\
(0.34)\end{array}$ & $\begin{array}{l}-0.35 \\
(0.49)\end{array}$ & $\begin{array}{c}0.07 \\
(0.45)\end{array}$ & $\begin{array}{l}-0.26 \\
(0.39)\end{array}$ & $\begin{array}{c}1.16 \\
(0.85)\end{array}$ & $\begin{array}{l}-0.05 \\
(0.42)\end{array}$ & $\begin{array}{l}-0.22 \\
(0.39)\end{array}$ & $\begin{array}{c}0.08 \\
(0.48)\end{array}$ \\
\hline Institutional quality & $\begin{array}{l}0.02 \\
(0.2)\end{array}$ & $\begin{array}{c}0.04 \\
(0.19)\end{array}$ & $\begin{array}{c}0.04 \\
(0.21)\end{array}$ & $\begin{array}{c}0.05 \\
(0.19)\end{array}$ & $\begin{array}{l}-0.43 \\
(0.44)\end{array}$ & $\begin{array}{l}0.05 \\
(0.2)\end{array}$ & $\begin{array}{c}0.05 \\
(0.19)\end{array}$ & $\begin{array}{c}0.05 \\
(0.19)\end{array}$ \\
\hline Ethnicity & $\begin{array}{l}-0.01 * * \\
(0.007)\end{array}$ & $\begin{array}{l}-0.01 * \\
(0.007)\end{array}$ & $\begin{array}{l}-0.01 \\
(0.007)\end{array}$ & $\begin{array}{c}-0.01 \\
(0.007)\end{array}$ & $\begin{array}{l}-0.04 \\
(0.03)\end{array}$ & $\begin{array}{l}-0.01 \\
(0.007)\end{array}$ & $\begin{array}{c}-0.01 \\
(0.007)\end{array}$ & $\begin{array}{l}-0.01^{*} \\
(0.007)\end{array}$ \\
\hline Terms of trade & $\begin{array}{l}0.12 \\
(0.08)\end{array}$ & $\begin{array}{c}0.13 \\
(0.07)\end{array}$ & $\begin{array}{l}0.16^{* *} \\
(0.06)\end{array}$ & $\begin{array}{l}0.16^{* *} \\
(0.07)\end{array}$ & $\begin{array}{c}0.05 \\
(0.11)\end{array}$ & $\begin{array}{l}0.16^{* *} \\
(0.06)\end{array}$ & $\begin{array}{l}0.16^{* *} \\
(0.07)\end{array}$ & $\begin{array}{l}0.14 * * \\
(0.06)\end{array}$ \\
\hline Education & $\begin{array}{c}1.96 \\
(1.27)\end{array}$ & $\begin{array}{c}1.58 \\
(1.27)\end{array}$ & $\begin{array}{l}2.85^{* *} \\
(1.29)\end{array}$ & $\begin{array}{l}2.68^{* *} \\
(1.28)\end{array}$ & $\begin{array}{l}4.43^{*} \\
(2.49)\end{array}$ & $\begin{array}{l}2.72 * * \\
(1.23)\end{array}$ & $\begin{array}{l}2.69 * * \\
(1.28)\end{array}$ & $\begin{array}{l}2.47 * * \\
(1.19)\end{array}$ \\
\hline Landlocked economies & $\begin{array}{l}-0.39 \\
(0.56)\end{array}$ & $\begin{array}{l}-0.11 \\
(0.53)\end{array}$ & $\begin{array}{c}0.22 \\
(0.45)\end{array}$ & $\begin{array}{c}0.41 \\
(0.51)\end{array}$ & $\begin{array}{c}0.19 \\
(0.91)\end{array}$ & $\begin{array}{c}0.28 \\
(0.45)\end{array}$ & $\begin{array}{c}0.39 \\
(0.49)\end{array}$ & $\begin{array}{c}0.27 \\
(0.45)\end{array}$ \\
\hline Ethnicity $\times$ Resource share & $\begin{array}{l}-0.12 \\
(0.3)\end{array}$ & $\begin{array}{l}-0.21 \\
(0.31)\end{array}$ & $\begin{array}{c}-0.62 * * \\
(0.27)\end{array}$ & $\begin{array}{c}-0.71 * * \\
(0.26)\end{array}$ & $\begin{array}{l}-1.06 \\
(0.68)\end{array}$ & $\begin{array}{l}-0.61^{* *} \\
(0.27)\end{array}$ & $\begin{array}{l}-0.66 * * \\
(0.29)\end{array}$ & $\begin{array}{l}-0.51 * * \\
(0.24)\end{array}$ \\
\hline $\begin{array}{l}\text { Institutional quality } x \\
\text { Resource share }\end{array}$ & $\begin{array}{l}8.3^{*} \\
(4.4)\end{array}$ & $\begin{array}{l}9.29 * * \\
(4.37)\end{array}$ & $\begin{array}{l}7.84 * * \\
(3.67)\end{array}$ & $\begin{array}{l}8.14^{* *} \\
(3.77)\end{array}$ & $\begin{array}{c}18.32 * * \\
(7.2)\end{array}$ & $\begin{array}{l}7.97 * * \\
(3.74)\end{array}$ & $\begin{array}{l}7.89 * * \\
(3.81)\end{array}$ & $\begin{array}{c}10.97 * * * \\
(3.31)\end{array}$ \\
\hline Decentralization & & $\begin{array}{l}-0.01 \\
(0.01)\end{array}$ & $\begin{array}{l}0.008 \\
(0.01)\end{array}$ & $\begin{array}{l}0.002 \\
(0.01)\end{array}$ & $\begin{array}{l}-0.001 \\
(0.03)\end{array}$ & $\begin{array}{l}0.004 \\
(0.01)\end{array}$ & $\begin{array}{l}-0.001 \\
(0.01)\end{array}$ & $\begin{array}{c}0.0006 \\
(0.0005)\end{array}$ \\
\hline $\begin{array}{l}\text { Decentralization } x \\
\text { Resource share }\end{array}$ & & & $\begin{array}{c}-0.39 * * * \\
(0.08)\end{array}$ & $\begin{array}{c}-0.46 * * * \\
(0.1)\end{array}$ & $\begin{array}{c}-0.71 * * \\
(0.27)\end{array}$ & $\begin{array}{c}-0.37 * * * \\
(0.09)\end{array}$ & $\begin{array}{c}-0.43^{* * *} \\
(0.09)\end{array}$ & $\begin{array}{c}-2.88 * * * \\
(0.49)\end{array}$ \\
\hline Adjusted R-squared & 0.7091 & 0.7183 & 0.7853 & 0.7733 & 0.6517 & 0.7827 & 0.7695 & 0.8005 \\
\hline Observations & 51 & 51 & 51 & 51 & 51 & 51 & 51 & 51 \\
\hline \multicolumn{9}{|c|}{ FIRST STAGE RESULTS } \\
\hline $\begin{array}{l}\text { Dependent variable: } \\
\text { Decentralization }\end{array}$ & \multicolumn{4}{|c|}{ Regressions (10) and (11) } & \multicolumn{4}{|c|}{ Regression (13) } \\
\hline Logarithm of land area & \multicolumn{4}{|c|}{$3.59 * * *(0.99)$} & \multicolumn{4}{|c|}{$4.93^{* * *}(0.91)$} \\
\hline Adjusted R-squared & \multicolumn{4}{|c|}{0.7823} & \multicolumn{4}{|c|}{0.8146} \\
\hline Observations & \multicolumn{4}{|c|}{51} & \multicolumn{4}{|c|}{51} \\
\hline F-Statistic & \multicolumn{4}{|c|}{17.2} & \multicolumn{4}{|c|}{21.16} \\
\hline
\end{tabular}

Standard errors are robust and appear in parentheses for independent variables. Superscripts correspond to a 10, 5 and 1\% level of significance. First stage regressions include all relevant variables. All regressions include an intercept. For description, sources, and descriptive statistics of variables, as well as list of economies included in each regression, see Appendices 2-4. 
TABLE 3. Cross-country growth regressions [panel with fixed effects, period: 1972-2008, in 9-

year intervals]

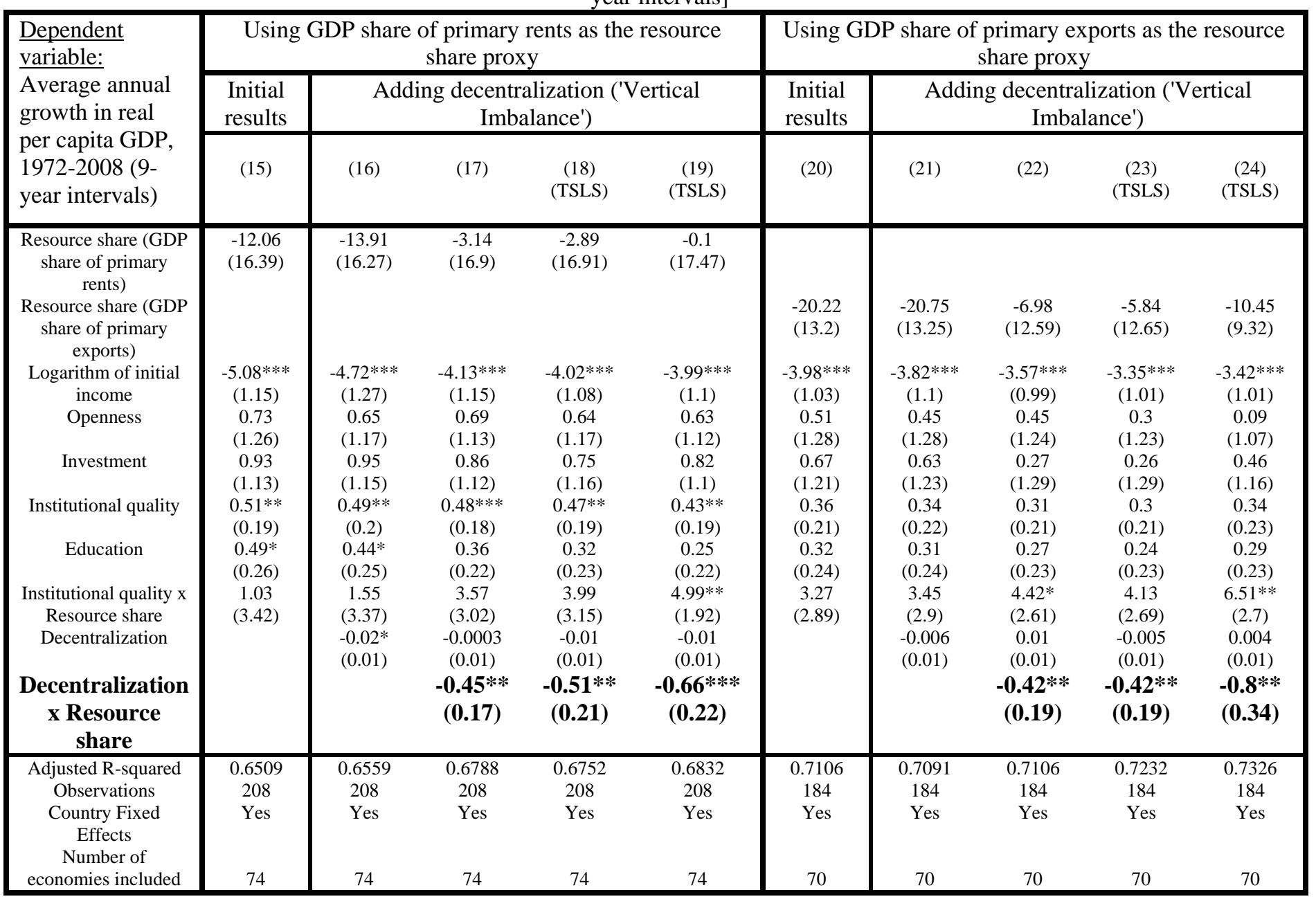

\begin{tabular}{|c|c|c|c|c|}
\hline \multicolumn{5}{|c|}{ FIRST STAGE RESULTS } \\
\hline Dependent variable: Decentralization & Regression (18) & Regression (19) & Regression (23) & Regression (24) \\
\hline $\begin{array}{l}\text { Level of democracy int-1 } \\
\text { Adjusted R-squared } \\
\text { Observations } \\
\text { F-Statistic }\end{array}$ & $\begin{array}{c}5.63 * * *(0.65) \\
0.7962 \\
208 \\
10.98\end{array}$ & $\begin{array}{c}5.65^{* * *}(0.93) \\
0.7942 \\
208 \\
10.86\end{array}$ & $\begin{array}{c}5.49 * * *(0.67) \\
0.7944 \\
184 \\
10.18\end{array}$ & $\begin{array}{c}5.55 * * *(0.67) \\
0.7934 \\
184 \\
10.25\end{array}$ \\
\hline Dependent variable: GDP share of primary rents/exports & Regression (18) & Regression (19) & Regression (23) & Regression (24) \\
\hline $\begin{array}{c}\text { GDP share of mineral rents in t-1 } \\
\text { Adjusted R-squared } \\
\text { Observations } \\
\text { F-Statistic }\end{array}$ & & $\begin{array}{c}0.32 * *(0.12) \\
0.9592 \\
208 \\
61.14\end{array}$ & & $\begin{array}{c}0.67 * * *(0.07) \\
0.9006 \\
184 \\
22.81\end{array}$ \\
\hline
\end{tabular}

Standard errors are robust, clustered by country, and appear in parentheses for independent variables. Superscripts correspond to a 10, 5 and $1 \%$ level of significance. In the first stage results only coefficient on the relevant instruments (level of democracy in $\mathrm{t}-1$, and GDP share of mineral rents in $\mathrm{t}-1$ ) are reported, yet regressions include all variables reported in the second stage results. Note that in regressions (18) and (23) only decentralization is instrumented (by the level of democracy in t-1), while in regressions (19) and (24) both decentralization and resource share are instrumented (the former by the level of democracy in t-1, and the latter by the GDP share of mineral rents in t-1). All regressions include an intercept. All variables are expressed as deviations from period means so that time fixed effects are controlled for in all regressions. For description and source of variables as well as list of economies included in each regression and descriptive statistics see Appendices 2-4. 
TABLE 4. Cross-country growth regressions, using the Revenue Raising Authority component of the 'Kearney Decentralization Index' as the decentralization index [panel with fixed effects, period:

1965-2000, in 5-year intervals]

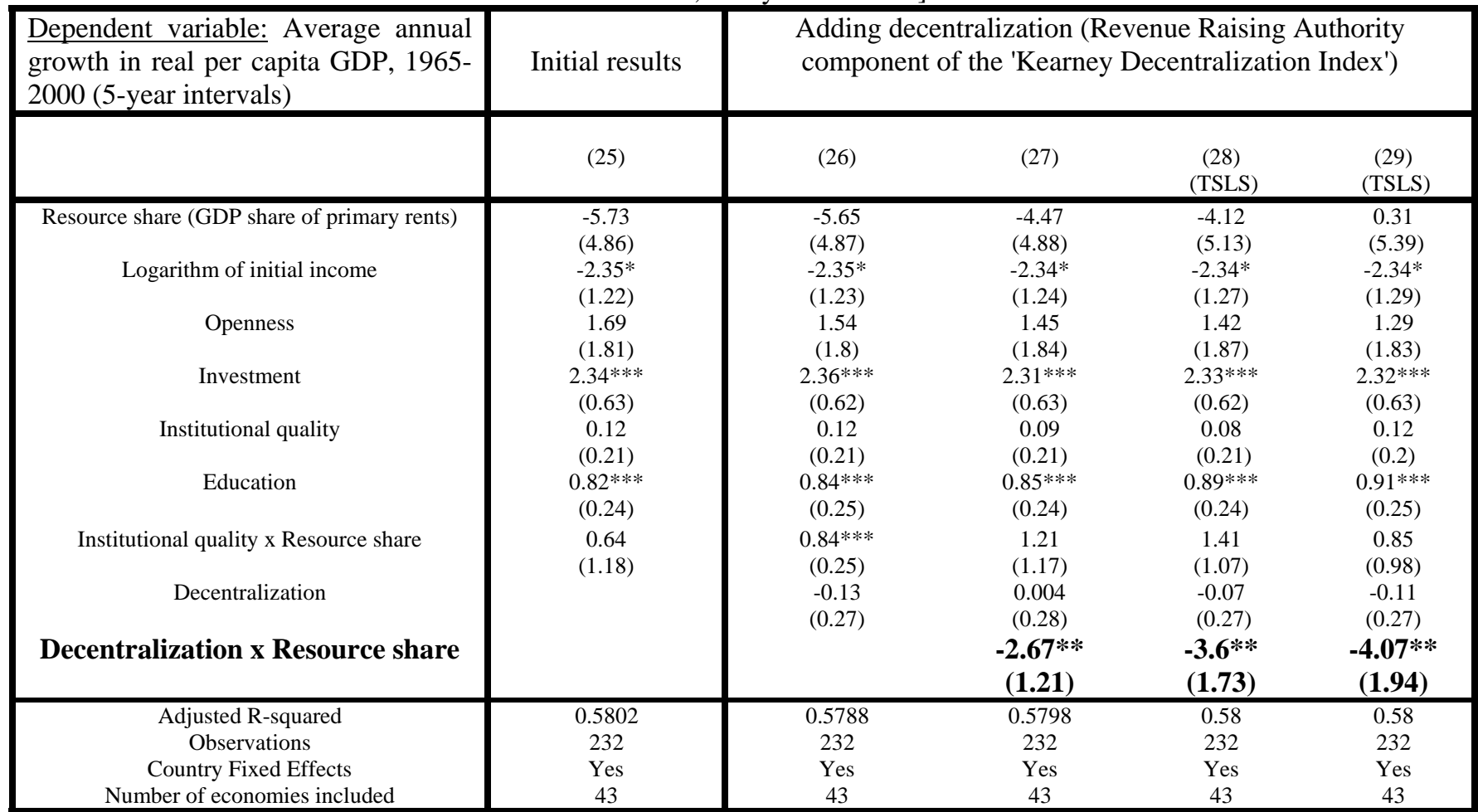

\begin{tabular}{|c|c|c|}
\hline \multicolumn{2}{|c|}{ FIRST STAGE RESULTS } \\
\hline Dependent variable: Decentralization & Regression & Regression \\
& $(28)$ & $(29)$ \\
& $0.06^{* *}$ & $0.07^{* *}$ \\
Level of democracy in t-1 & $(0.03)$ & $(0.03)$ \\
& 0.7904 & 0.8368 \\
Adjusted R-squared & 232 & 232 \\
Observations & 18.42 & 18.55 \\
F-Statistic & Regression & Regression \\
& $(28)$ & $(29)$ \\
\hline Dependent variable: GDP share of primary rents & & $0.39^{* * *}$ \\
GDP share of mineral rents in t-1 & & $(0.12)$ \\
& & 0.9145 \\
Adjusted R-squared & & 232 \\
Observations & & 38.72 \\
F-Statistic & & \\
\hline
\end{tabular}

Standard errors are robust, clustered by country, and appear in parentheses for independent variables. Superscripts correspond to a 10, 5 and $1 \%$ level of significance. In the first stage results only the coefficient on the relevant instruments (level of democracy in $\mathrm{t}-1$, and GDP share of mineral rents in t-1) is reported, yet the regression includes all variables reported in the second stage results. Note that in regression (28) only decentralization is instrumented (by the level of democracy in t-1), while in regression (29) both decentralization and resource share are instrumented (the former by the level of democracy in t-1, and the latter by the GDP share of mineral rents in t-1).All regressions include an intercept. All variables are expressed as deviations from period means so that time fixed effects are controlled for in all regressions. For description and source of variables as well as list of economies included in each regression see Appendices 2 and 3. For descriptive statistics see Appendix 4. 


\section{Appendix 1: Additional Graphs}

Note that all graphs are at the federal-state level (so that each point represents a federal-state within the respective federation). All data was retrieved from the corresponding statistical bureaus of each federation.

\section{Agglomeration VS. Resources}
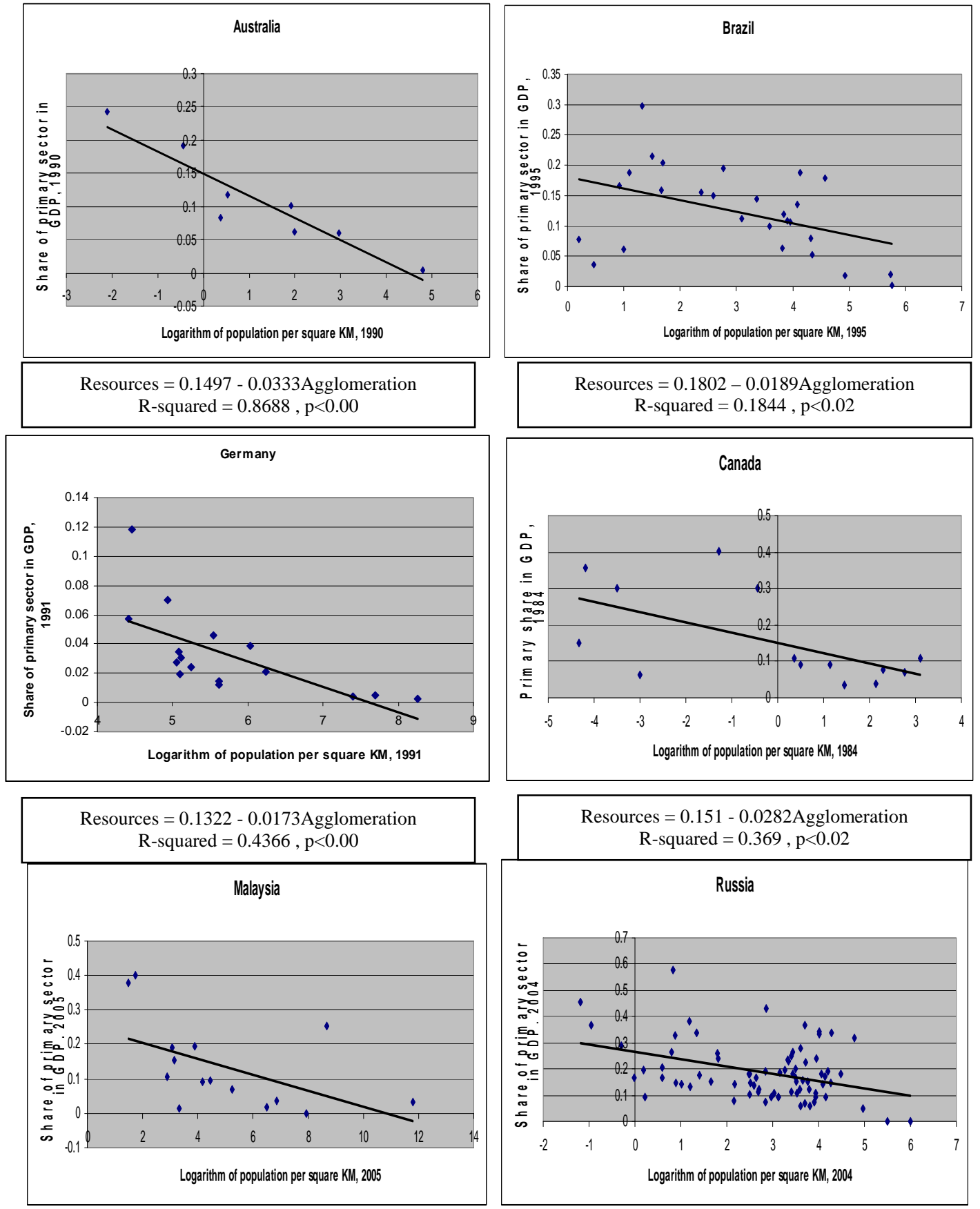

Resources $=0.2531-0.0233$ Agglomeration R-squared $=0.274, \mathrm{p}<0.04$ 

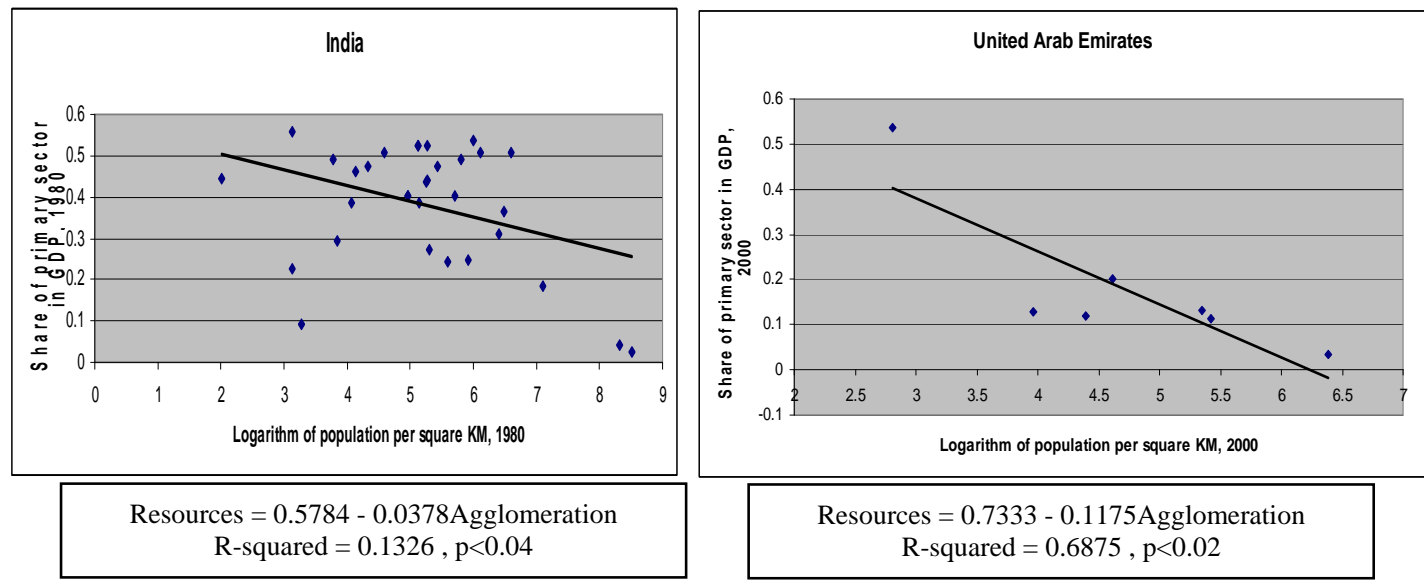

Resources $=0.7333-0.1175$ Agglomeration R-squared $=0.6875, \mathrm{p}<0.02$

Agglomeration Growth VS. Resources (conditional on initial level of agglomeration)
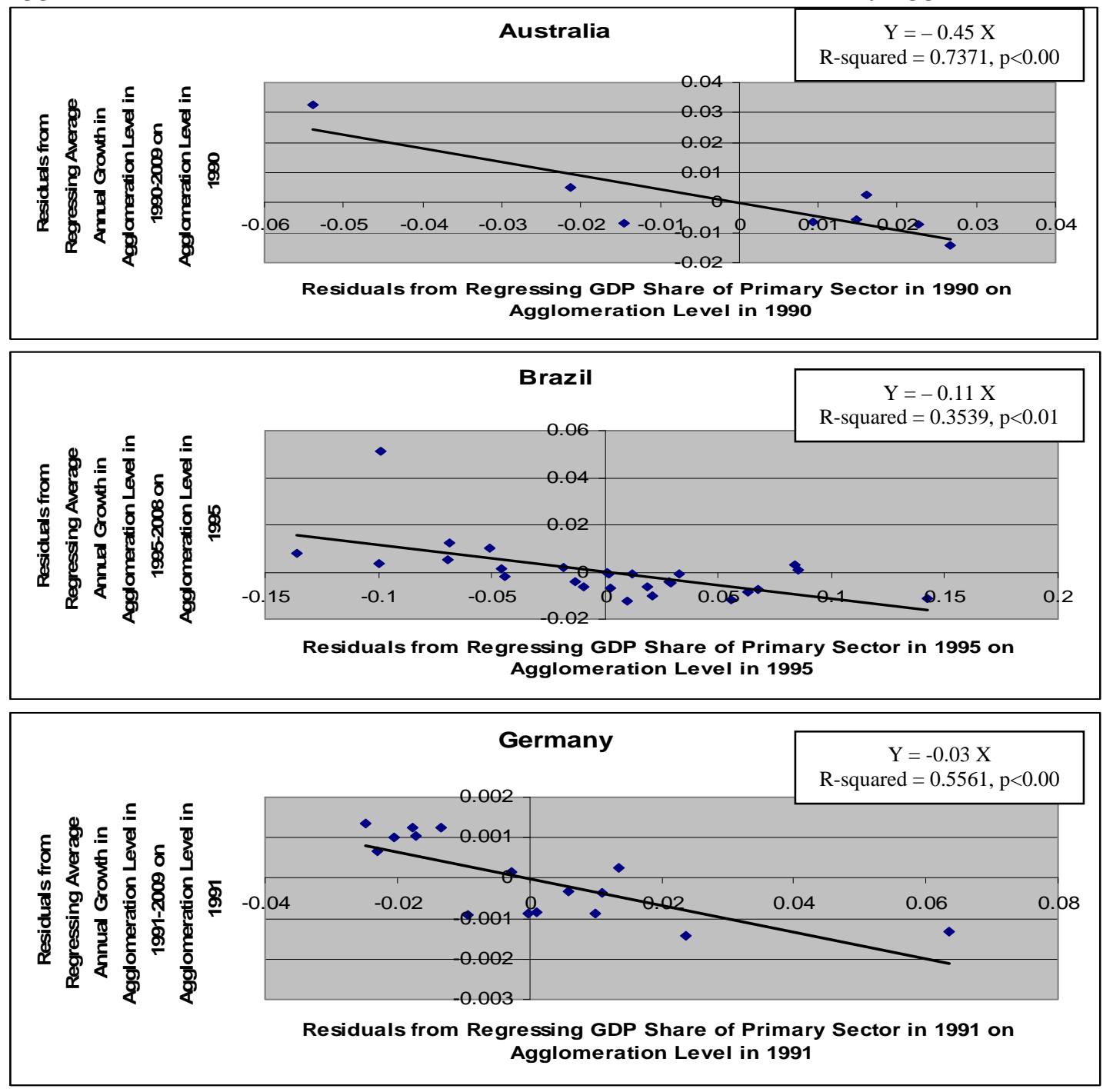


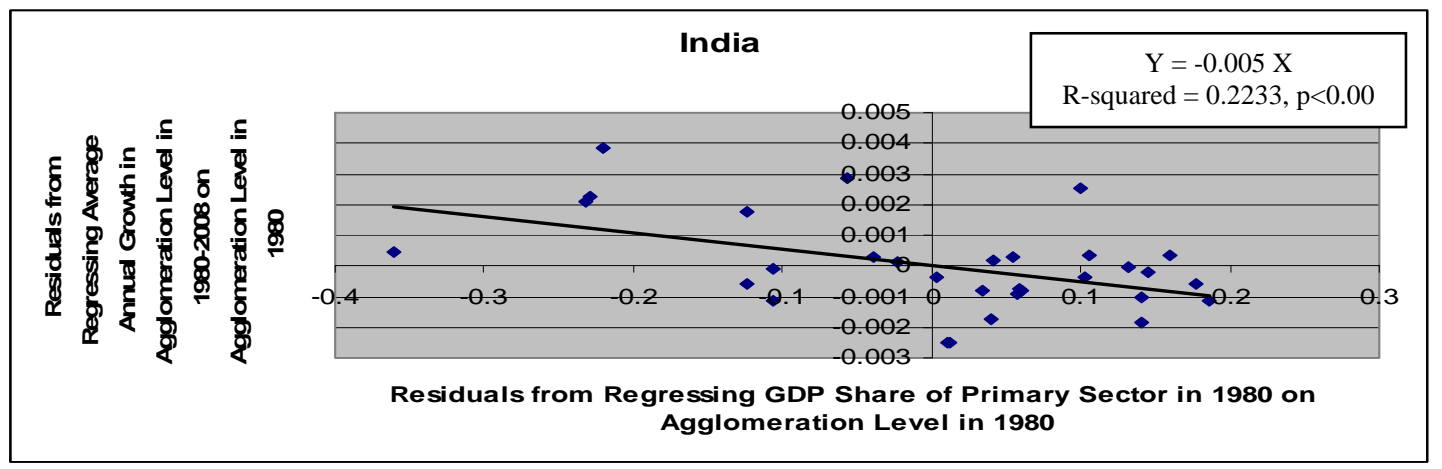

Investment Growth VS. Resources (conditional on initial level of investment)
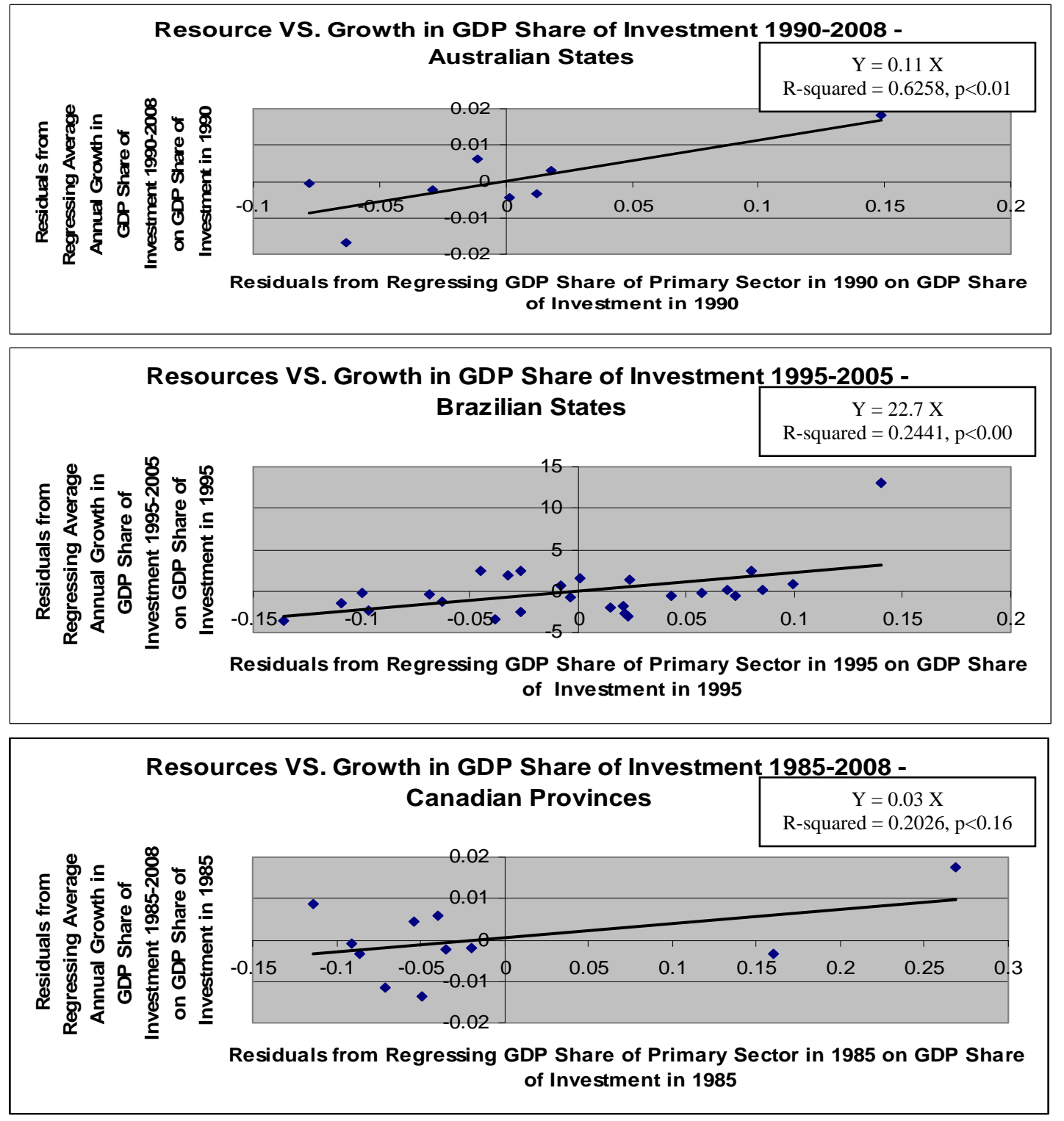

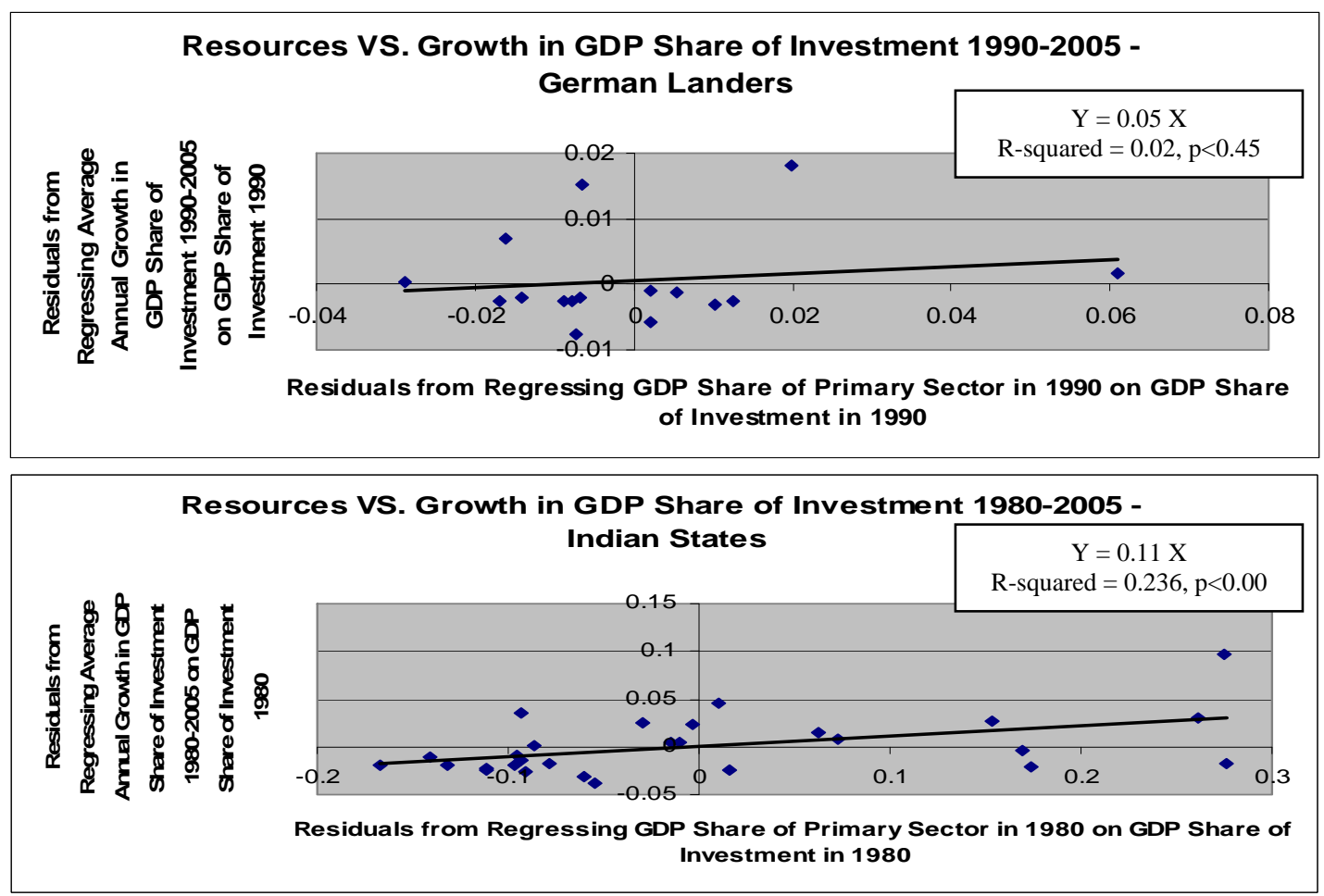

\section{Appendix 2: List of Variables Used in the Regressions}

\section{Tables 1 - 2 (Cross-section estimations)}

Source of variables in these tables is Sachs and Warner (1997), unless stated otherwise (variable names as in Sachs and Warner (1997), or otherwise their source appear in parentheses).

Growth (dependent variable): Measure 1 (used in all regressions, except (11)): Average annual growth in real per capita GDP in the years 1970-1990 expressed as a number between -4 and 6 (gea7090).

Measure 2 (used in Regression (11)): Average annual growth in real per capita GDP in the years 1970-2008 expressed as a number between -2 and 18 (Source: World Development Indicators).

Logarithm of initial income: The log of real per capita GDP in 1970 (lgdpea70).

Resource share: Measure 1 (used in Table 1): Share of mineral production in total GDP in 1970 expressed as a number between 0 and 1 (snr).

Measure 2 (used in Table 2): Share of natural capital in total GDP in 2000 expressed as a number between 0 and 1 (Source: World Bank 2006).

Openness: The fraction of years over the period 1970-1990 in which the country is rated as economically 'open', according to Sachs and Warner (1997) expressed as a number between 0 and 1 (open6590).

Investment: The log of the ratio of real gross domestic investment to real GDP, averaged over the period 1970-1989 (linv7089).

Institutional quality: The rule of law index from the International Country Risk Guide, in 1982, expressed as a number between one and six, six presenting best institutional quality and one least (rl). 
Ethnicity: Measure of ethno-linguistic fractionalization; measures the probability that two randomly-selected people from a country will not belong to the same ethnic or linguistic group, expressed as a number between 0 and 100 (ethling).

Terms of Trade: The average annual growth rate in the log of the external terms of trade between 1970 and 1990 expressed as a number between -10 and 10. External terms of trade are defined as the ratio of an export price index to an import price index (dtt7090).

Education: Secondary school enrollment rate in 1970 expressed as a number between 0 and 1 (sec70).

Landlocked economies: A dummy variable for landlocked economies (access).

Decentralization: 'Vertical Imbalance': The extent to which sub-national governments rely on their own revenue sources for their expenditures, measured in initial year (closest to 1970, in case data is available for one of the years in the 1970-1975 period) and expressed as a number between 0 and 100. Source: World Bank Fiscal Decentralization Indicators.

'Potential Vulnerability': The share of non-agglomerated area in total area in 2001 (Source: Center for International Earth Science Information Network at Columbia University) multiplied by the 'Vertical Imbalance' measure, expressed as a number between 0 and 100 .

'Modified Potential Vulnerability': The share of general government final consumption expenditure in total GDP in 1972 (Source: World Development Indicators) multiplied by the 'Vertical Imbalance' measure, expressed as a number between 0 and 100 .

Land area: The logarithm of land area in square kilometers; used as an instrument for decentralization in Tables 1 and 2 (Regressions (4), (6), (10), and (13)). Source: World Bank Development Indicators.

\section{Tables 3 - 4 (Panel estimations)}

Note that Table 3 employs a panel that covers the period of 1972-2008 with 9-year intervals, whereas Table 4 employs a panel that covers the period of 1965-2000. Thus, variables correspond to those periods and time intervals in either case. Unless stated otherwise, variables are measured in the initial year of the corresponding time interval.

Growth (dependent variable): Measure 1 (used in Table 3): Average annual growth in real per capita GDP in the years 1972-2008, in 9-year intervals, expressed as a number between -9 and 13. Source: World Bank Development Indicators.

Measure 2 (used in Table 4): Average annual growth in real per capita GDP in the years 1965-2000, in 5-year intervals, expressed as a number between -12 and 22. Source: World Bank Development Indicators.

Logarithm of initial Income: The log of real GDP per capita. Source: World Bank Development Indicators.

Resource share: Measure 1: GDP share of primary rents, expressed as a number between 0 and 1. Source: World Bank Development Indicators.

Measure 2: GDP share of primary exports, expressed as a number between 0 and 1 . Source: World Bank Development Indicators. 
Measure 3 (used in Table 3 (Regressions (19), (24) and (29)) as an instrument for GDP share of primary rents or exports): GDP share of mineral rents in t-1, expressed as a number between 0 and 1. Source: World Bank Development Indicators.

Openness: Share of total trade (exports and imports) in total GDP, expressed as a number between 0 and 4. Source: Penn World Table 7.0.

Investment: The log of the ratio of real gross domestic investment to real GDP. Source: Penn World Table 7.0.

Institutional quality: Civil Liberties Index, expressed as a number between one and seven, seven presenting best institutional quality and one least. Source: Freedom House.

Education: Average years of total schooling for population aged 15 and over, expressed as a number between 0 and 13. Source: Barro and Lee (2010).

Decentralization: 'Vertical Imbalance' (used in Table 3): The extent to which subnational governments rely on their own revenue sources for their expenditures, expressed as a number between 0 and 100. Source: World Bank Fiscal Decentralization Indicators.

'Kearney Decentralization Index' (used in Table 4): The Revenue-Raising component of the 'Kearney Decentralization Index' (available for the years 1965-1995) expressed as a number between zero and four with four having the highest level of revenueraising autonomy and zero the least. Source: Arzaghi and Henderson (2005).

Democracy: The level of democracy; used as an instrument for decentralization in Tables 3 and 4 (Regressions (18), (19), (23), (24), (28) and (29)). Democracy level is computed as the average level in the 10 years preceding to the initial year in the corresponding time interval, and expressed as a number between 1 and 10 where 10 represents the highest level of democracy, and 1 the lowest. Source: Polity IV Project, Integrated Network for Societal Conflict Research.

\section{Appendix 3: List of Countries Covered in Each Table}

Table 1: Australia, Austria, Belgium, Bolivia, Brazil, Canada, Chile, Colombia, Costa Rica, Denmark, Dominican Republic, Ecuador, Finland, France, West Germany, Greece, Guatemala, Honduras, India, Indonesia, Iran, Ireland, Israel, Italy, Kenya, Korea Republic, Malawi, Malaysia, Mexico, Netherlands, New Zealand, Nicaragua, Norway, Pakistan, Paraguay, Peru, Philippines, Portugal, Senegal, Spain, Sri Lanka, Sudan, Sweden, Switzerland, Thailand, Trinidad and Tobago, Tunisia, United Kingdom, United States, Uruguay, Venezuela, Zambia. Table 2: Australia, Austria, Belgium, Bolivia, Brazil, Canada, Chile, Colombia, Costa Rica, Denmark, Dominican Republic, Ecuador, Finland, France, West Germany, Greece, Guatemala, Honduras, India, Indonesia, Iran, Ireland, Israel, Italy, Kenya, Korea Republic, Malawi, Malaysia, Mexico, Netherlands, New Zealand, Nicaragua, Norway, Pakistan, Paraguay, Peru, Philippines, Portugal, Senegal, Spain, Sri Lanka, Sweden, Switzerland, Thailand, Trinidad and Tobago, Tunisia, United Kingdom, United States, Uruguay, Venezuela, Zambia. Table 3 (Regressions (15)-(19)): Albania, Australia, Austria, Belgium, Bolivia, Botswana, Brazil, Bulgaria, Canada, Chile, China, Colombia, Costa Rica, Croatia, Czech Republic, Denmark, Dominican Republic, Ecuador, Estonia, Fiji, Finland, France, Gambia, Germany, Greece, Guatemala, Honduras, Hungary, Iceland, India, Indonesia, Iran, Ireland, Israel, Italy, Kenya, Korea Republic, Latvia, Lithuania, Luxemburg, Malawi, Malaysia, Mauritius, 
Mexico, Moldova, Mongolia, Netherlands, New Zealand, Nicaragua, Norway, Pakistan, Panama, Papua New Guinea, Paraguay, Peru, Philippines, Poland, Portugal, Romania, Russian Federation, Senegal, Slovak Republic, Slovenia, Spain, Sri Lanka, Swaziland, Sweden, Switzerland, Thailand, Tunisia, Uganda, United Kingdom, United States, Zambia, Zimbabwe. Table 3 (Regression (20)-(24)): Albania, Australia, Austria, Belgium, Bolivia, Brazil, Bulgaria, Canada, Chile, China, Colombia, Costa Rica, Croatia, Czech Republic, Denmark, Dominican Republic, Ecuador, Estonia, Fiji, Finland, France, Gambia, Germany, Greece, Guatemala, Honduras, Hungary, Iceland, India, Indonesia, Iran, Ireland, Israel, Italy, Korea Republic, Latvia, Lithuania, Malawi, Malaysia, Mauritius, Mexico, Moldova, Mongolia, Netherlands, New Zealand, Nicaragua, Norway, Pakistan, Panama, Papua New Guinea, Paraguay, Peru, Philippines, Poland, Portugal, Romania, Russian Federation, Senegal, Slovak Republic, Slovenia, Spain, Sri Lanka, Sweden, Switzerland, Thailand, Tunisia, United Kingdom, United States, Zambia, Zimbabwe. Table 4: Algeria, Argentina, Australia, Bangladesh, Brazil, Cameroon, Canada, Chile, China, Colombia, Ecuador, Egypt, France, Germany, Ghana, Great Britain, Greece, Hungary, India, Indonesia, Italy, Japan, Kenya, Korea Republic, Malaysia, Mexico, Mozambique, Nepal, Netherlands, Pakistan, Peru, Philippines, Poland, Romania, Russian Federation, Spain, Sri Lanka, Syria, Thailand, United States, Uganda, Venezuela, Zaire. 
Appendix 4: Descriptive Statistics of Variables in Each Table

$\underline{\text { Tables } 1 \text { and } 2}$

\begin{tabular}{|c|c|c|c|c|}
\hline Variable & Mean & $\begin{array}{l}\text { Standard } \\
\text { Deviation }\end{array}$ & Minimum & Maximum \\
\hline Growth, 1970-1990 (53) & 1.3 & 1.6 & -3.09 & 5.7 \\
\hline Growth, 1970-2008 (53) & 3.4 & 3.1 & -1.2 & 17.77 \\
\hline $\begin{array}{l}\text { GDP share of mineral } \\
\text { output (53) }\end{array}$ & 0.04 & 0.08 & 0 & 0.37 \\
\hline $\begin{array}{l}\text { GDP share of natural } \\
\text { capital (52) }\end{array}$ & 0.02 & 0.05 & 0.0001 & 0.38 \\
\hline $\begin{array}{l}\text { Logarithm of initial } \\
\text { income (53) }\end{array}$ & 8.65 & 0.86 & 6.76 & 9.95 \\
\hline Openness (53) & 0.5 & 0.45 & 0 & 1 \\
\hline Investment (53) & 2.86 & 0.49 & 1.33 & 3.61 \\
\hline Institutional quality (53) & 3.56 & 2.005 & 1 & 6 \\
\hline Ethnicity (53) & 36.89 & 28.35 & 0 & 89 \\
\hline Terms of trade (53) & -0.41 & 2.32 & -4.69 & 7.38 \\
\hline Education (52) & 0.17 & 0.14 & 0.005 & 0.54 \\
\hline $\begin{array}{l}\text { Landlocked economies } \\
\text { (53) }\end{array}$ & 0.13 & 0.34 & 0 & 1 \\
\hline Vertical Imbalance (53) & 67.15 & 23.94 & 7.02 & 99.82 \\
\hline $\begin{array}{l}\text { Potential Vulnerability } \\
\text { (53) }\end{array}$ & 62.47 & 24.75 & 3.96 & 98.98 \\
\hline $\begin{array}{l}\text { Modified Potential } \\
\text { Vulnerability (53) }\end{array}$ & 9.63 & 4.31 & 0.97 & 20.55 \\
\hline $\begin{array}{l}\text { Logarithm of land area } \\
\text { (53) }\end{array}$ & 12.65 & 1.97 & 6.54 & 16.03 \\
\hline
\end{tabular}


$\underline{\text { Table } 3}$

\begin{tabular}{lcccc}
\hline Variable & Mean & $\begin{array}{c}\text { Standard } \\
\text { Deviation }\end{array}$ & Minimum & Maximum \\
\hline Growth, 1972-2008 (312) & 2.13 & 2.75 & -8.06 & 12.98 \\
$\begin{array}{l}\text { GDP share of primary } \\
\text { rents (388) }\end{array}$ & 0.05 & 0.09 & 0 & 0.78 \\
$\begin{array}{l}\text { GDP share of primary } \\
\text { exports (322) }\end{array}$ & 0.06 & 0.08 & 0.001 & 0.64 \\
$\begin{array}{l}\text { GDP share of mineral } \\
\text { rents (389) }\end{array}$ & 0.03 & 0.08 & 0 & 0.78 \\
$\begin{array}{l}\text { Logarithm of initial } \\
\text { income (398) }\end{array}$ & 8.75 & 1.25 & 4.91 & 11.4 \\
Openness (462) & 0.71 & 0.42 & 0.02 & 3.24 \\
Investment (462) & 24.4 & 9.23 & 5.17 & 70.31 \\
Institutional quality (376) & 4.86 & 1.83 & 1 & 7 \\
Education (400) & 7.17 & 2.82 & 0.57 & 10 \\
Vertical Imbalance (250) & 45.72 & 21.25 & 0.91 & 97.38 \\
Level of democracy (454) & 5.95 & 3.76 & 0 & 10 \\
\hline
\end{tabular}

Table 4

\begin{tabular}{lcccc}
\hline Variable & Mean & $\begin{array}{c}\text { Standard } \\
\text { Deviation }\end{array}$ & Minimum & Maximum \\
\hline Growth, 1965-2000 (333) & 2.14 & 2.98 & -11.39 & 22.38 \\
$\begin{array}{l}\text { GDP share of primary } \\
\text { rents (313) }\end{array}$ & 0.07 & 0.1 & 0 & 0.93 \\
$\begin{array}{l}\text { GDP share of mineral } \\
\text { rents (315) }\end{array}$ & 0.05 & 0.1 & 0 & 0.92 \\
$\begin{array}{l}\text { Logarithm of initial } \\
\text { income (381) }\end{array}$ & 7.49 & 1.57 & 4.43 & 10.51 \\
$\begin{array}{l}\text { Openness (382) } \\
\begin{array}{l}\text { Investment (379) } \\
\text { Institutional quality (256) }\end{array}\end{array}$ & 0.39 & 0.24 & 0.05 & 1.92 \\
$\begin{array}{l}\text { Education (441) } \\
\text { Kearney Decentralization }\end{array}$ & 1.31 & 8.81 & 1.34 & 58.31 \\
Index (380) & 5.45 & 2.19 & 1 & 7 \\
Level of democracy (425) & 4.36 & 2.95 & 0.13 & 12.71 \\
\hline
\end{tabular}

